\title{
Multi-method geochemical characterization of groundwater from a hypogene karst system
}

\author{
Marjan Temovski ${ }^{1} \cdot$ Marianna Túri $^{1} \cdot$ István Futó ${ }^{1} \cdot$ Mihály Braun $^{1} \cdot$ Mihály Molnár ${ }^{1} \cdot$ László Palcsu $^{1}$
}

Received: 8 June 2020 / Accepted: 9 December 2020 / Published online: 21 January 2021

(C) The Author(s) 2021

\begin{abstract}
An approach, combining several geochemical methods, was used to determine the groundwater properties and components of a hypogene karst system, where sampling is restricted only to the spring sites, and with a limited number of available sampling locations. Radiogenic isotopes $\left({ }^{3} \mathrm{H},{ }^{14} \mathrm{C}\right)$ were used to constrain the groundwater mean residence time and separate different groundwater components. Noble gases, stable isotopes of water $\left(\delta^{18} \mathrm{O}, \delta^{2} \mathrm{H}\right)$, dissolved inorganic carbon $\left(\delta^{13} \mathrm{C}\right)$ and dissolved sulfate $\left(\delta^{34} \mathrm{~S}, \delta^{18} \mathrm{O}\right)$, and major ion and trace element composition were used to identify the source of water, its chemical evolution and water-rock interactions, as well as to identify the contribution and composition of endogenic gases. This approach was applied to three low-temperature thermal springs located in Mariovo (North Macedonia) associated with fossil hypogene caves, previously identified by morphological and geochemical studies of caves and cave deposits. Based on the obtained results, the main studied springs represent an output part of a regional hypogene karst groundwater system with a deep-circulating $(\sim 1 \mathrm{~km})$, old $(\sim 15 \mathrm{ka})$, thermal $\left(\geq 60{ }^{\circ} \mathrm{C}\right)$ water, which mixes with young $(<50$ years $)$, cold $\left(<14{ }^{\circ} \mathrm{C}\right)$ and shallow epigene karst groundwater. The output parts are structurally controlled, at the interception of low topography and deep faults, along which the groundwater interacts with deep-seated gases, dominantly $\mathrm{CO}_{2}$ of metamorphic origin $\left(\delta^{13} \mathrm{C}\right.$ of $+4.5 \%$ o VPDB), with some contribution of mantle helium. The thermal karst groundwater interacts at depth with volcanic rocks from the nearby Neogene-Quaternary volcanic complex, as well as with metamorphic basement rocks and granitoids.
\end{abstract}

Keywords Stable isotopes $\cdot$ Radioactive isotopes $\cdot$ Hydrochemistry $\cdot$ Hypogene karst $\cdot$ North Macedonia

\section{Introduction}

Hypogene karstification is a relatively recent scientific paradigm in the understanding of the formation of karst systems (e.g. Klimchouk et al. 2017 and references therein). It addresses karst systems that develop due to bedrock dissolution by groundwater that recharges the karst rock formation from below (Klimchouk 2007). In contrast to the much more widespread epigene karst, where the chemical capacity to dissolve the bedrock is dominantly due to dissolved $\mathrm{CO}_{2}$ acquired at the surface, more diverse genetic mechanisms are present in hypogene karst systems due to a variety of geochemical

Marjan Temovski

temovski.marjan@atomki.hu

1 Isotope Climatology and Environmental Research Centre, Institute for Nuclear Research, Bem tér 18/c, Debrecen 4026, Hungary processes (Ford and Williams 2007; Klimchouk 2007; Palmer 2007).

As hypogene karst systems generally become accessible only after being intercepted by surface erosional processes, the most common approach to studying them is to characterize the cave morphology and deposits in fossil cave systems (e.g. Audra et al. 2002; De Waele et al. 2016; Plan et al. 2012; Spötl et al. 2016; Temovski et al. 2013). A complementary approach is to study the geochemical properties of the groundwater associated with hypogene karst systems.

Various geochemical methods and approaches have been used in the study of groundwater systems (Clark 2015). Many of them have been also applied to groundwater in carbonate aquifers that might be associated with hypogene karst processes (i.e. aquifers with thermal waters, high gas concentrations etc.), in order to identify sources of fluids, flow-paths and geochemical processes. A combined use of hydrochemistry and stable isotopes, including sulfur and strontium isotopes, has been applied to identify water-rock interactions and separate different groundwater flows associated with the thermal 
springs in Derbyshire, England, UK (Gunn et al. 2006). Gary and Sharp (2006) identified interaction of the groundwater at Sistema Zacatón (Mexico) with Pleistocene volcanic rocks based on strontium isotopes, and related the speleogenesis of the deep phreatic caves to volcanic derived $\mathrm{H}_{2} \mathrm{~S}$ and $\mathrm{CO}_{2}$. Hydrochemistry and isotopic composition of dissolved inorganic carbon has been used to identify the source and amount of geogenic $\mathrm{CO}_{2}$ related to the carbonate aquifers in the Appenine Region in Italy (e.g. Chiodini et al. 2000). A similar approach, combined also with noble gases, was used to identify geogenic gases in groundwater related to the giant collapse dolines in the Konya Closed Basin, Turkey (Bayari et al. 2009b, 2017), and sources of fluids in the deep phreatic cave Hranicka Abyss in Czechia (Sracek et al. 2019). Wynn et al. (2010) used sulfur isotopes to identify the sources of dissolved sulfur species in the thermal waters associated with sulfuric acid speleogenesis at Cerna Valley, Romania. Different radionuclides have been used to identify groundwater flow-paths and their mean residence times. Erőss et al. (2012) applied uranium, radium and radon to identify mixing of fluids in the Buda thermal karst system (Hungary) and to estimate the temperature and chemical composition of the end-members. Radiocarbon and tritium have been used to estimate the mean residence time of groundwater such as in the Bükk thermal karst system, Hungary (Hertelendi et al. 1995), the coastal thermal springs of Apulia, Italy (Santaloia et al. 2016), and the Konya Closed Basin in Tukey (Bayari et al. 2009a).

The approach in many of these examples involves using a relatively high number of sampling locations and/or time series of certain geochemical parameters covering longer periods (e.g. Bayari et al. 2009a, b; Erőss et al. 2020; Galdenzi et al. 2008; Mádl-Szőnyi and Tóth 2015). Spring waters often provide the main insight into the geochemical properties of these hypogene karst groundwater systems (e.g. Gunn et al. 2006; Mádl-Szőnyi and Tóth 2015; Palmer et al. 2017; Santaloia et al. 2016), due to their ease of access or due to lack of available boreholes. However, these discharge areas, generally located at points of low topography and controlled by major structural elements (Klimchouk 2007), are zones of convergence of discharge from different groundwater flow systems (local, intermediate and regional), allowing for mixing of groundwater with different geochemical composition (e.g. Erőss et al. 2012; Minissale et al. 2002). In such cases, to study the geochemical properties of a distinctive groundwater flow system, information about the geochemical composition of the end-members and their contributing ratios is required, which is not always attainable.

Here, an approach is presented of a combined use of several geochemical methods in the study of groundwater associated with hypogene karst systems, where sampling of the groundwater systems is restricted to only a small number of springs. Such an approach allowed for identification of the different components of groundwater where the end-member geochemical compositions were unknown. The approach was applied to Mariovo area in North Macedonia, where hypogene speleogenesis has been previously demonstrated based on morphological and geochemical studies of caves and cave deposits, and dissolution of carbonate rock due to cooling of $\mathrm{CO}_{2}$-rich thermal groundwater identified as the main speleogenetic process, coupled locally with sulfuric acid speleogenesis and ghost-rock weathering (Temovski et al. 2013; Temovski 2016). The insight obtained from this groundwater geochemical study was then used to provide an improved conceptual model of the hypogene karst system.

\section{Research area}

The study sites are located in the southern parts of the Republic of North Macedonia, in Mariovo, a hilly to mountainous area deeply incised by the valleys of Crna Reka and its tributaries (Fig. 1). The area spreads on both sides of the contact between the Vardar Zone and the Pelagonian Massif. These major tectonic zones are overlain by structures formed within the extensional tectonics of the South Balkan Extensional System (Burchfiel et al. 2008; Dumurdžanov et al. 2005), mainly the Mariovo Basin, bounded to the south by the mountainous terrain of the Kožuf-Kozjak volcanic centers (also known as Voras in Greece).

Karst is developed here in marble of supposedly Precambrian and Cambrian age, as well as in Cretaceous and Triassic limestone and dolomite, and varieties of PlioceneQuaternary travertine. The Precambrian and Cambrian age of the Pelagonian marble formations has been recently questioned, assigning them Triassic to Jurassic age based on preliminary local ${ }^{87} \mathrm{Sr} /{ }^{86} \mathrm{Sr}$ measurements and various studies of its continuation to the south in Greece (Most 2003). The main structures are mainly spread in the NNW-SSE direction, with the carbonate rocks part of a series of nappe structures, except for the travertine deposits which are found either within, or topping, the Pliocene-Quaternary sedimentary sequences, or on Pleistocene river terraces. This long NNWSSE karst stripe is cut transversely by the gorge-like valleys of Crna Reka (at Podot) and its tributary Buturica (at Melnica), where the three low-temperature (warm) thermal karst springs, that are the main study sites, are found (Fig. 1).

Hypogene karstification in the area has been characterized on the basis of cave morphology and cave deposits (Temovski 2016). The main speleogenetic mechanism is hydrothermal speleogenesis, i.e. dissolution of carbonate rock due to cooling of $\mathrm{CO}_{2}$-rich thermal water, with increased geothermal gradient attributed to the Neogene-Quaternary Kožuf-Kozjak volcanism. At places, due to local geological or lithological control, this is coupled with other hypogenic processes such as sulfuric acid speleogenesis (Temovski et al. 2013, 2018) or ghost-rock weathering, i.e. preferential dissolution of calcite due to 


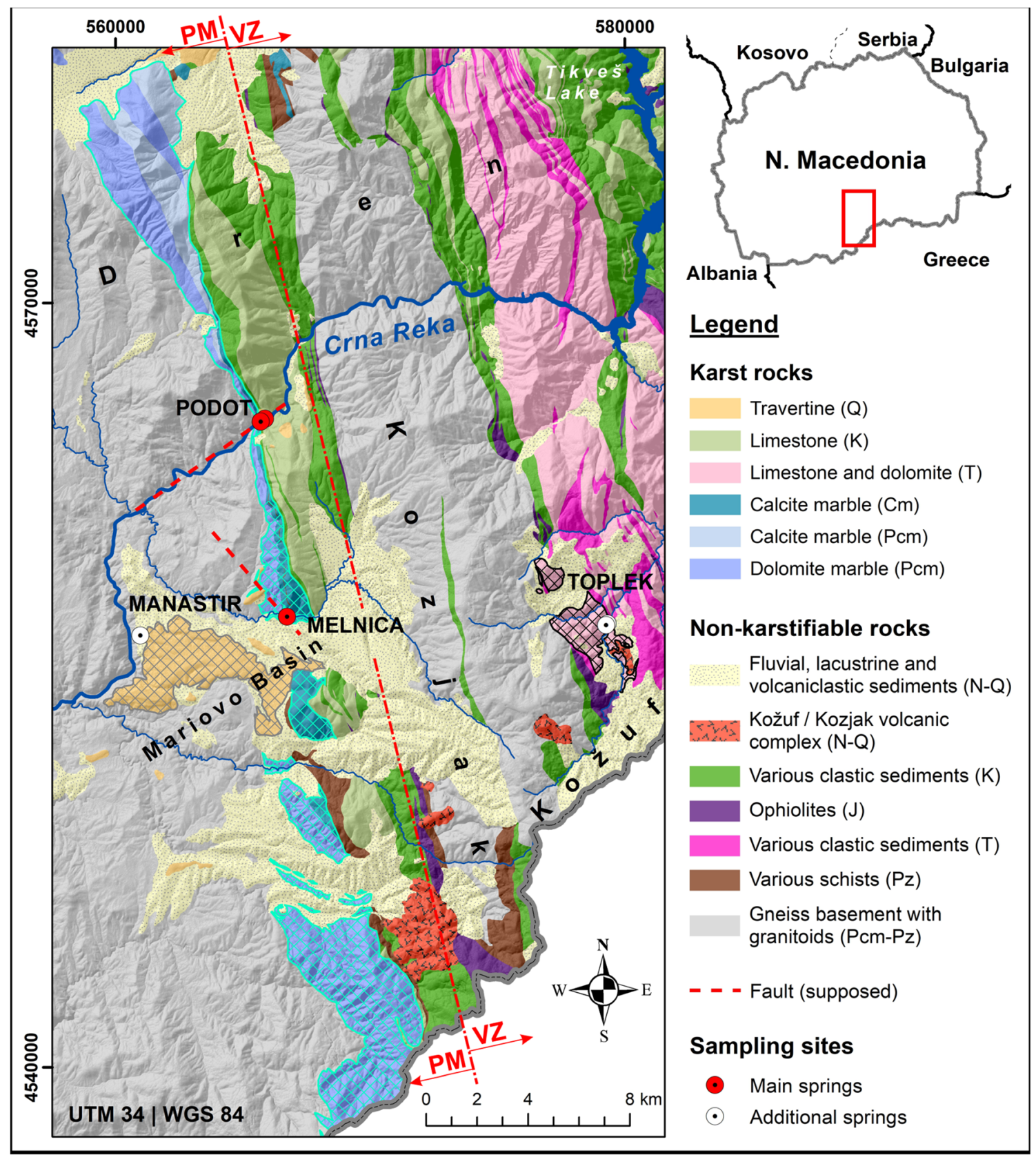

Fig. 1 Location and geological setting of the study area. The approximate boundary between the Pelagonian Massif (PM) and the Vardar Zone (VZ) is also indicated. The potential recharge areas for different springs are also

cooling of thermal waters, leaving in-situ dolomitic sand residue (Temovski 2016, 2017).

Melnica spring is located at the riverbed in the small gorge of Buturica Valley, with groundwater discharging from calcite marble along a lens of schists (Fig. 2). It is located $100 \mathrm{~m}$ below Provalata Cave, a fossil hypogene cave where both $\mathrm{CO}_{2}$-based hydrothermal and sulfuric acid speleogenesis were identified (Temovski et al. 2013, 2018). In Crna Reka, at Podot locality (Figs. 1 and 3), the active thermal cave Karši Podot is developed in dolomite marble on the right valley side, and on a 3-m high river terrace on the opposite side of the indicated: Gugjakovo Springs and Karši Podot - cyan outline; Melnica Spring - cyan crosshatch; Manastir - grey crosshatch; Toplek 2 and Toplek 4 - black crosshatch

river, the lukewarm Gugjakovo springs discharge from travertine deposits.

Preliminary findings from a previous sampling campaign in 2016 (Temovski and Palcsu 2018) indicated that the water at these springs is a mixture of cold and thermal groundwater, with possible interaction with the Kožuf-Kozjak volcanics.

In addition to these, three more springs were also included: Manastir, Toplek 2 and Toplek 4. Although they do not belong to the same groundwater systems, they were added as comparative sites, representing either a young fresh groundwater system (e.g. Manastir and Toplek 4) or a low- 


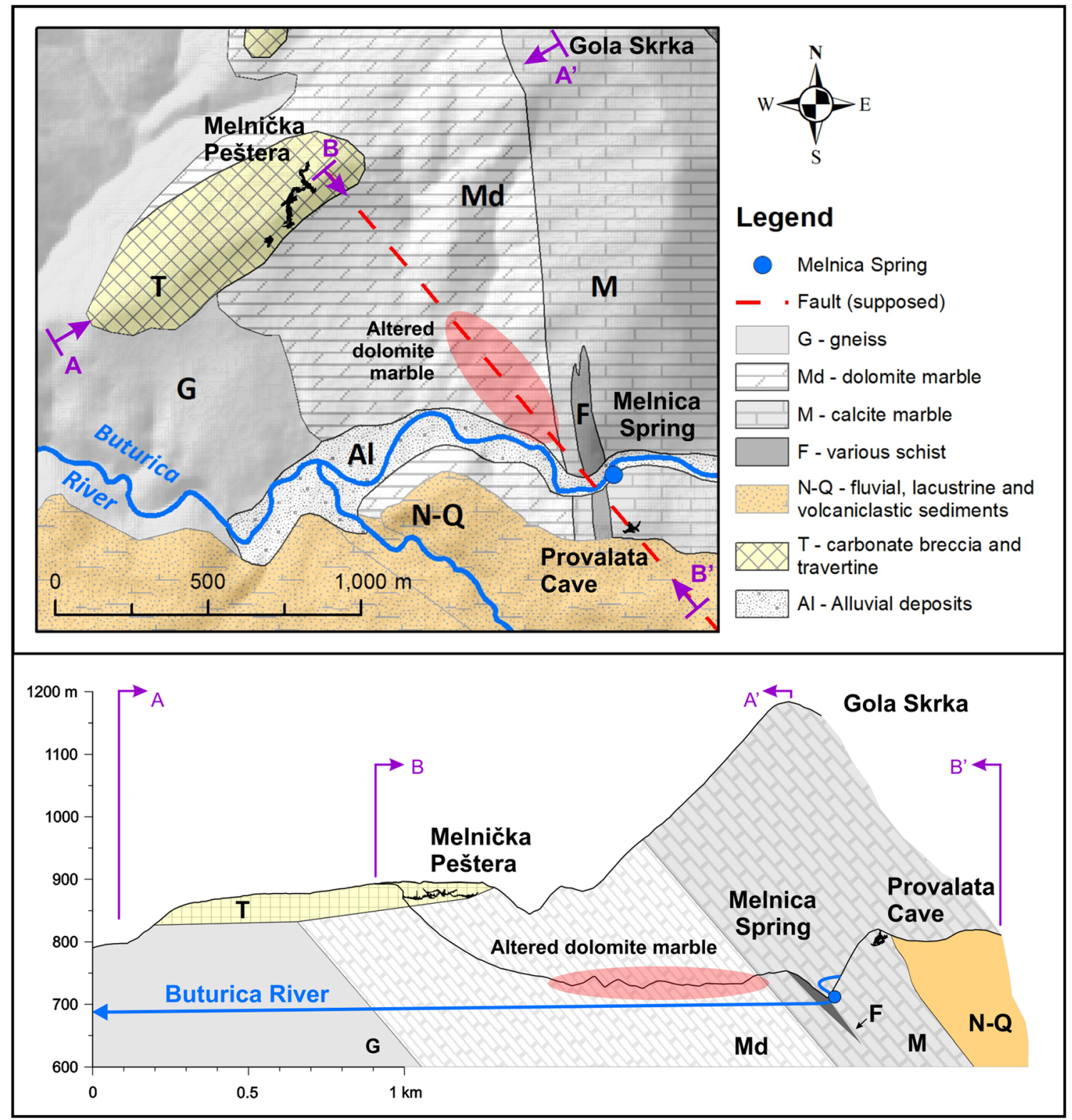

Fig. 2 Geological setting of Melnica Spring and adjacent hypogene karst features

temperature thermal groundwater system with similar geochemical composition (e.g. Toplek 2). Manastir is a cold spring, discharging from a large plateau of travertine deposits topping the Mariovo Pliocene-Pleistocene sedimentary sequence. Toplek 2 and Toplek 4 are located further east, on the opposite side of Kozjak Mt, in the foothills of Kožuf Mt (Fig. 1). Toplek 2 has similar temperature to Melnica and Karši Podot, while Toplek 4 is cold and intermittent. Toplek 2 and 4 are located very close to each other and discharge from dolomite rocks, near the Allchar Carlin-type ore complex (Palinkaš et al. 2018). Previous geochemical studies of Toplek 2 (Boev and Lepitkova 2003; Boev and Jančev 2014) show high concentrations of elements characteristic of the ore deposits (e.g. As, Sb, Tl).

\section{Methodology}

\section{Methodological approach}

As the sampling network for the groundwater systems was restricted to only their springs (no available boreholes), and located in a remote area, with a limited number of sampling locations, the approach relied on the combined use of several geochemical methods.

Radiocarbon $\left({ }^{14} \mathrm{C}\right)$ and tritium $\left({ }^{3} \mathrm{H}\right)$ combined with noble gases $\left({ }^{3} \mathrm{H}_{-}{ }^{3} \mathrm{He}\right.$ method) were used to identify the mean residence time of the groundwater and to separate young and old components. Water stable isotopes and noble gases were used to identify the source of water and conditions at groundwater 


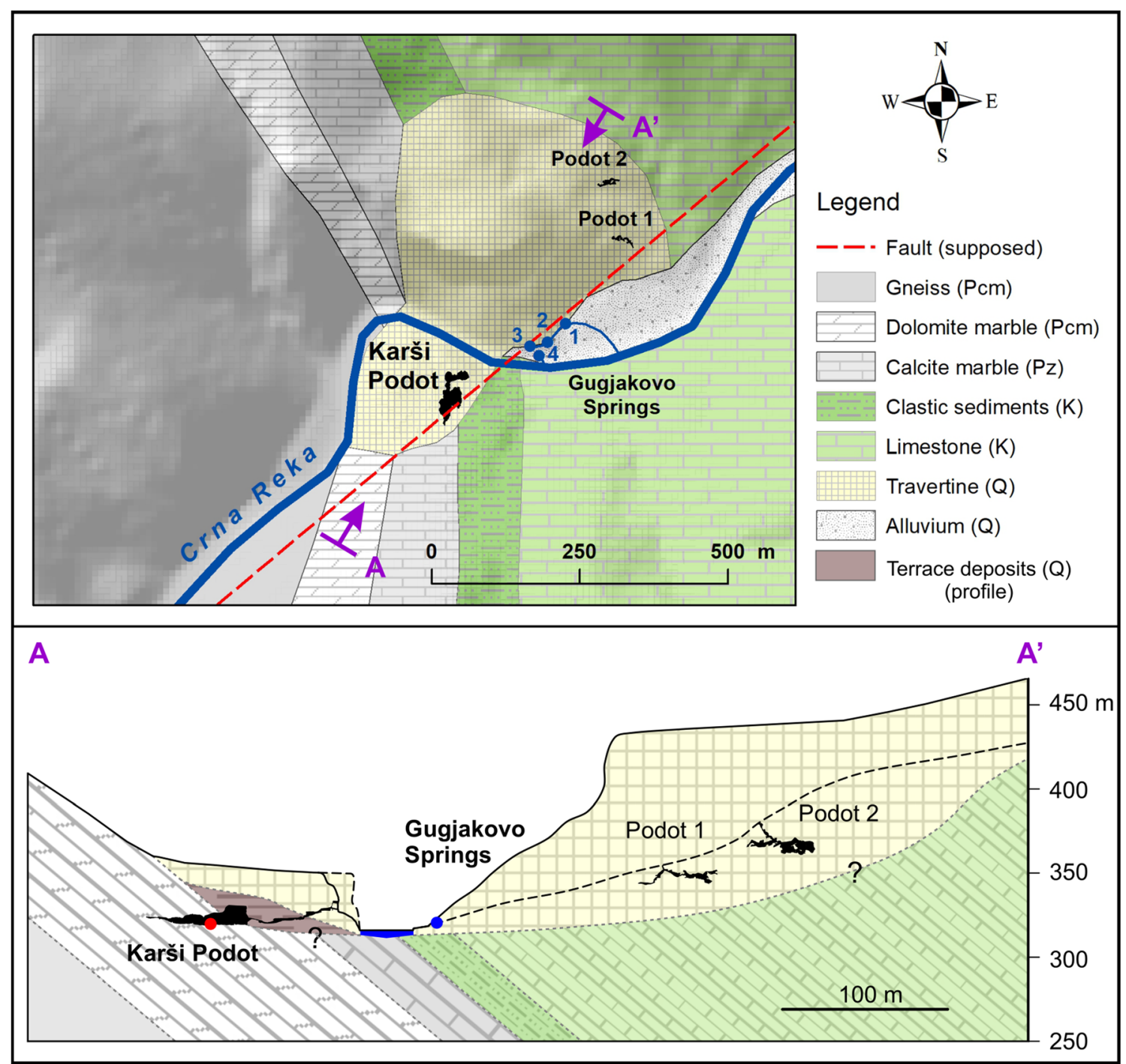

Fig. 3 Geological setting of Gugjakovo Springs and Karši Podot Cave

recharge. Major ion and trace element composition of the water, as well isotopic composition of the dissolved inorganic carbon (DIC) and dissolved sulfate, were used to interpret the chemical evolution of the groundwater and identify possible interaction with nonkarstic rocks. The concentration and carbon isotope composition of the DIC were used to identify different carbon sources and model the carbon isotope composition of endogenic $\mathrm{CO}_{2}$. The obtained fractions for different carbon sources (soil and endogenic $\mathrm{CO}_{2}$ and carbonate rock) were then used to correct the radiocarbon age of the old groundwater by constraining the contribution of ${ }^{14} \mathrm{C}$-free carbon. Noble gas concentrations and isotopic composition were also used to identify endogenic noble gases. The applied methodological approach is conceptually illustrated in Fig. 4, showing the use of characteristic geochemical parameters to identify different properties of the groundwater system. Further explanation is also given on the approaches and calculation steps used to identify $\mathrm{CO}_{2}$ sources (section 'Sources of $\mathrm{CO}_{2}$ and deconvolution of carbon components in DIC'), noble gas recharge temperatures (section 'Noble gas recharge temperatures'), different groundwater components, and their carbon isotopic composition and mean residence times (sections 'Calculating the age and fraction of the young groundwater component', 'Estimating the carbon isotope composition of the groundwater end-member', 'Correction for ${ }^{14} \mathrm{C}$ free dilution of DIC and calculating the age of the old groundwater').

\section{Analytical methods}

Field sampling was carried out in September 2018 at all locations, except Toplek 4, which was sampled in March 2019 when also Toplek 2 was resampled. Spring water temperature, electrical conductivity (EC) and $\mathrm{pH}$ were determined on-site using a Multi 340i multiparameter instrument. Total alkalinity was determined in the field by acidimetric titration, using $\mathrm{HCl}$ 


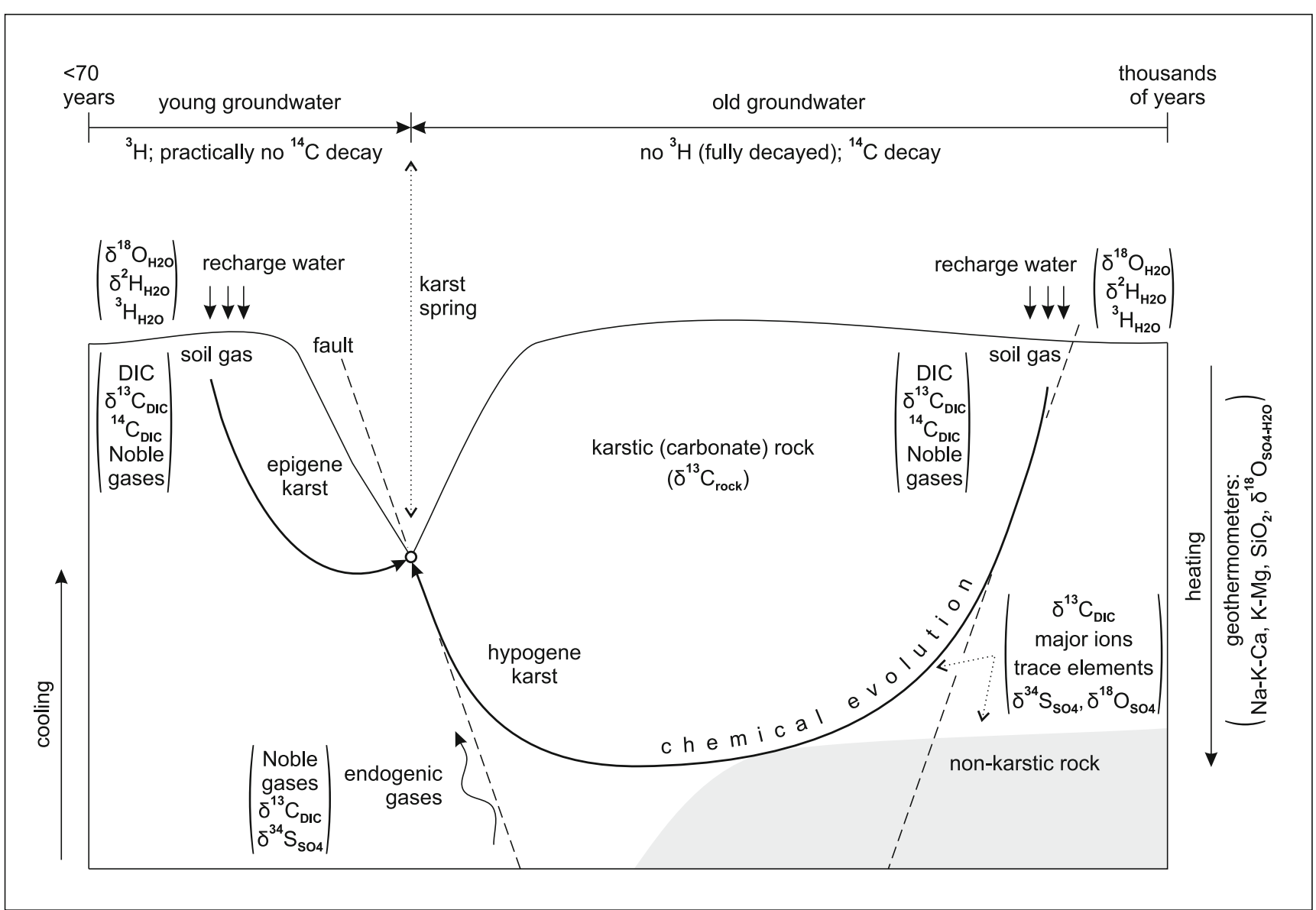

Fig. 4 Conceptual representation of the applied methodological approach with indication of the analyzed geochemical parameters that were used to identify different properties of the karst groundwater system

$0.1 \mathrm{~N}$ as titrating agent and methyl orange as indicator. Samples were collected for laboratory analyses to determine water chemistry, stable isotopes, radiocarbon, tritium and dissolved noble gases. Water stable isotope composition, temperature, $\mathrm{pH}$ and $\mathrm{EC}$ of the three main springs were analyzed more frequently in addition to the main field campaign, when samples for full geochemical analysis were collected. The full list of those measurements is given in the electronic supplementary material (ESM).

Samples for determination of anions were filtered and stored without additional treatment, whereas samples for determination of cations and trace elements were acidified after filtration by addition of suprapure nitric acid. Major anion concentrations were measured on a Metrohm 850 Professional IC, and cations on an Agilent 4100 MP-AES. Major ion charge balance error was less than $5 \%$. Trace element concentrations were measured using Agilent 8800 Triple Quadrupole ICP-MS. Stable isotope analyses of water and DIC were done on an automated GASBENCH II sample preparation device attached to a Thermo Finnigan Delta ${ }^{\text {PLUS }}$ XP mass spectrometer (Vodila et al. 2011). Hydrogen and oxygen isotopes of the water are given as $\delta^{2} \mathrm{H}$ and $\delta^{18} \mathrm{O}$ values relative to Vienna Standard Mean Ocean Water (VSMOW), and DIC carbon isotopes are expressed as $\delta^{13} \mathrm{C}$ values relative to Vienna Pee-Dee Belemnite (VPDB). The precision of the measurements is better than $\pm 0.15 \%$ o for $\delta^{18} \mathrm{O}, \pm 2 \%$ o for $\delta^{2} \mathrm{H}$, and $\pm 0.08 \%$ for $\delta^{13} \mathrm{C}$. Oxygen and sulfur stable isotope composition of the dissolved $\mathrm{SO}_{4}{ }^{2-}$ were analyzed with a Thermo Finnigan Delta ${ }^{\text {PLUS }}$ XP mass spectrometer attached to an elemental analyzer (Flash EA). Oxygen and sulfur isotopes of the dissolved $\mathrm{SO}_{4}{ }^{2-}$ are given as $\delta^{18} \mathrm{O}$ values relative to VSMOW, and as $\delta^{34} \mathrm{~S}$ values relative to Vienna Canyon Diablo Troilite (VCDT). An individual $\delta^{18} \mathrm{O}$ and $\delta^{34} \mathrm{~S}$ measurement has a standard deviation (SD) of $\pm 0.3 \%$ and \pm $0.4 \%$, respectively.

Radiocarbon $\left({ }^{14} \mathrm{C}\right)$ analyses of the water samples were done by accelerator mass spectrometry (AMS), following standard procedures (Molnár et al. 2013a), on an EnvironMICADAS ${ }^{14} \mathrm{C}$ AMS facility (Molnár et al. 2013b). The DIC fraction of the water samples was extracted by acid $\left(85 \% \mathrm{H}_{3} \mathrm{PO}_{4}\right)$ reaction in a vacuum-tight reaction vessel. The produced $\mathrm{CO}_{2}$ gas was cleaned and separated along an on-line gas handling system and graphitized by the sealed tube $\mathrm{Zn}$ based graphitization method (Rinyu et al. 2013). Radiocarbon results are expressed in absolute pMC units (percent Modern Carbon). The water samples for dissolved noble gases were 
stored in copper tubes sealed by stainless-steel pinch-off clamps. Noble gas measurements were performed by a VG5400 (Fisons Instrument) and a Helix SFT (Thermo Scientific) noble gas mass spectrometers (Papp et al. 2012). Noble gas concentrations are given as cubic centimeters of gas at Standard Temperature and Pressure per gram $\left(\mathrm{cm}^{3} \mathrm{STP} / \mathrm{g}\right)$. Tritium $\left({ }^{3} \mathrm{H}\right)$ concentration in water was determined using the ${ }^{3} \mathrm{He}$ ingrowth method (Palcsu et al. 2010). Tritium results are expressed as tritium units (TU), with precision of the measurements better than $0.1 \mathrm{TU}$.

All analytical measurements were done at the Isotope Climatology and Environmental Research Centre, Institute for Nuclear Research, Debrecen, Hungary.

The distribution of aqueous carbon species and saturation indices for aragonite, calcite and dolomite, as well as $\mathrm{pCO}_{2}$, were calculated using PHREEQC Version 3 software (Parkhurst and Appelo 2013). Statistical analyses of chemical parameters were done with IMB SPSS Statistics v.23 using normalized values.

\section{Sources of $\mathrm{CO}_{2}$ and deconvolution of carbon components in DIC}

To identify the sources of $\mathrm{CO}_{2}$ the applied approach first separates the amount of carbon contributed to the DIC by dissolution of carbonates $\left(\mathrm{C}_{\text {rock }}\right)$ from the external carbon $\left(\mathrm{C}_{\text {ext }}\right)$, i.e. carbon from $\mathrm{CO}_{2}$ not accounted for by dissolution of carbonate rocks (Chiodini et al. 2000, 2004; Crossey et al. 2009). $\mathrm{C}_{\text {rock }}$ can be calculated from the water chemistry data, as $\mathrm{C}_{\text {rock }}=\mathrm{Ca}^{2+}+\mathrm{Mg}^{2+}-\mathrm{SO}_{4}{ }^{2-}$, where the amount of $\mathrm{Ca}$ and $\mathrm{Mg}$ derived from dissolution of carbonate rocks is corrected for dissolution of sulfates (Chiodini et al. 2000). $\mathrm{C}_{\mathrm{ext}}$ is then calculated as $\mathrm{C}_{\text {ext }}=\mathrm{DIC}-\mathrm{C}_{\text {rock. }}$. The $\delta^{13} \mathrm{C}$ of the external carbon can be estimated from the following equation (Chiodini et al. 2000): $\left(\delta^{13} \mathrm{C}_{\mathrm{ext}} \times \mathrm{C}_{\mathrm{ext}}\right)=\left(\delta^{13} \mathrm{C}_{\mathrm{DIC}} \times \mathrm{DIC}\right)$ $-\left(\delta^{13} \mathrm{C}_{\text {rock }} \times \mathrm{C}_{\text {rock }}\right)$. For $\delta^{13} \mathrm{C}_{\text {rock }}$ the average values of measured samples of the carbonate rocks from the studied aquifers were used (Fig. 5).

The obtained $\delta^{13} \mathrm{C}_{\text {ext }}$ ranged from values characteristic of soil-derived $\mathrm{CO}_{2}$, to values reflecting mixture of soil $\mathrm{CO}_{2}$ and variable amounts of endogenic $\mathrm{CO}_{2}$. To estimate the $\delta^{13} \mathrm{C}$ of the endogenic $\mathrm{CO}_{2}$, the mixing of a soil end-member (with $\delta^{13} \mathrm{C}$ defined by samples with $\delta^{13} \mathrm{C}_{\text {ext }}$ reflecting soil-derived $\mathrm{CO}_{2}$ and a range of values for $\mathrm{C}_{\mathrm{ext}}$ ), with an endogenic endmember was modeled. The $\delta^{13} \mathrm{C}$ value of the endogenic endmember was constrained by the best fit mixing line between $\mathrm{C}_{\text {ext }}$ and $\delta^{13} \mathrm{C}_{\text {ext }}$ values of springs that are located next to each other, which, based on their geochemical composition and proximity, represent mixtures with variable contribution of the same end-members, and as such, they should fall on the same mixing line (section 'Stable isotope composition of DIC and the source of $\left.\mathrm{CO}_{2}{ }^{\prime}\right)$. The fractions of carbon in DIC derived from soil $\mathrm{CO}_{2}\left(f_{\text {soil }}\right)$ and endogenic $\mathrm{CO}_{2}\left(f_{\text {endogenic }}\right)$ at each spring can then be calculated from the binary mixing model using the equation: $f_{\text {soil }}=\left[\left(\delta^{13} \mathrm{C}_{\mathrm{ext}}-\delta^{13} \mathrm{C}_{\text {endogenic }}\right) /\right.$ $\left.\left(\delta^{13} \mathrm{C}_{\text {soil }}-\delta^{13} \mathrm{C}_{\text {endogenic }}\right)\right] / f_{\text {ext }}$, where $\delta{ }^{13} \mathrm{C}_{\text {soil }}$ is the soil endmember value, $\delta^{13} \mathrm{C}_{\text {endo }}$ is the modeled endogenic endmember value, $f_{\text {ext }}$ is the fraction of external carbon in DIC calculated as $f_{\text {ext }}=\mathrm{C}_{\text {ext }} / \mathrm{DIC}$ and $f_{\text {endogenic }}=1-f_{\text {soil }}$. The carbon in DIC derived from dissolution of carbonate rocks $\left(f_{\text {rock }}\right)$ can be calculated as $f_{\text {rock }}=\mathrm{C}_{\text {rock }} / \mathrm{DIC}$, and the total carbon balance is expressed as DIC $=f_{\text {soil }}+f_{\text {endogenic }}+f_{\text {rock }}=1$.

\section{Noble gas recharge temperatures}

The noble gas recharge temperatures (NGTs) reflect the temperature during recharge at which the groundwater was equilibrated to the soil air noble gas concentrations (AeschbachHertig and Solomon 2013). The NGTs were estimated by using all noble gases except $\mathrm{He}$, which usually has higher concentration due to contribution from other sources (crustal, mantle). The noble gas concentration in air, besides the temperature, depends also on air pressure, which varies with elevation. An estimation on the recharge elevation was made by extracting the mean elevations from a digital elevation model (DEM) for the outcrops of the carbonate formations likely contributing to these aquifers (Fig. 1). NGT values were calculated using the NobleBook excel worksheet (AeschbachHertig et al. 2000, 2008). As the recharge elevations are an average value, the estimated NGTs are also reflecting an average recharge temperature of water infiltrated at supposedly different elevations. The uncertainty in the NGTs due to recharge elevation uncertainty (taken as 1SD from mean elevations) ranged from 0.4 to $1.6^{\circ} \mathrm{C}$, which is $4-11 \%$ of the calculated NGT value.

\section{Calculating the age and fraction of the young groundwater component}

The age of the young groundwater cannot be determined based only on ${ }^{3} \mathrm{H}$ data, due to possible ${ }^{3} \mathrm{H}$ contribution from the thermonuclear testing in the $1950-1960$ s (bomb peak ${ }^{3} \mathrm{H}$ ). By combining ${ }^{3} \mathrm{H}$ and noble gas data, based on the accumulation of ${ }^{3} \mathrm{He}\left({ }^{3} \mathrm{He}_{\text {trit }}\right)$ from the decay of ${ }^{3} \mathrm{H}$ (half-life of 12.32 years), an apparent $\left({ }^{3} \mathrm{H}^{3} \mathrm{He}\right)$ age (expressed in years) can be calculated using the decay formula $t=-17.77 \times \ln \left[{ }^{3} \mathrm{H} /\right.$ $\left.\left({ }^{3} \mathrm{H}+{ }^{3} \mathrm{He}_{\text {trit }}\right)\right]$, which represents the period since the ${ }^{3} \mathrm{H}$-bearing water reached the groundwater (Schlosser et al. 1988). ${ }^{3} \mathrm{H}$ in the water recharging the aquifer before the thermonuclear testing, i.e. older than 1953 (assuming $4 \mathrm{TU}$ for ${ }^{3} \mathrm{H}$ in precipitation), would have decayed by the sampling time (2018) to a value of $<0.1 \mathrm{TU}$. When plotted on a graph showing the ${ }^{3} \mathrm{H}$ in precipitation decayed to the sampling time, samples with $>0.1$ TU that are below the precipitation curve represent mixture of old ${ }^{3} \mathrm{H}$-free groundwater and young groundwater. By using the ${ }^{3} \mathrm{H}-{ }^{3} \mathrm{He}$ apparent ages to constrain the recharge period of 
Fig. 5 Carbon stable isotope composition of the carbonate rocks in the studied aquifers. Open circles - measured values; solid circles - mean values; error bars - 1SD (standard deviation)

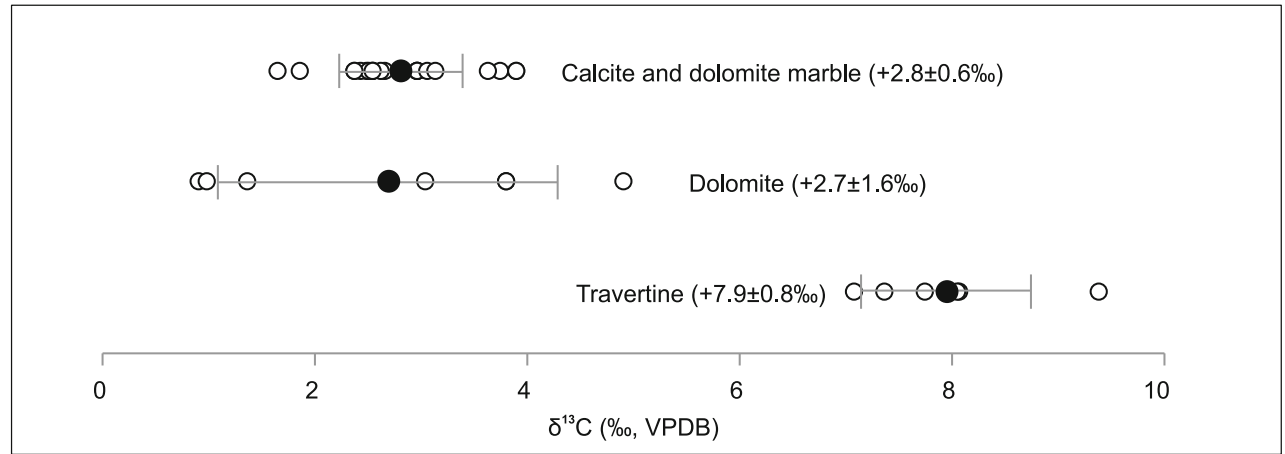

the young component, the fraction of the young groundwater can be estimated from the measured ${ }^{3} \mathrm{H}$ concentration of the groundwater and the expected recharge ${ }^{3} \mathrm{H}$ concentration obtained from the precipitation ${ }^{3} \mathrm{H}$ dataset for the given recharge period, decayed to the sampling time. For the precipitation ${ }^{3} \mathrm{H}$ concentrations, as there are no historical data available for the area, the data from the Vienna GNIP (Global Network of Isotopes in Precipitation) station was used, both monthly and yearly datasets.

\section{Estimating the carbon isotope composition of the groundwater end-members}

If it is assumed that the young groundwater DIC evolved due to carbonate dissolution under a system closed to soil $\mathrm{CO}_{2}$, then the ${ }^{14} \mathrm{C}$ of the young component can be calculated from ${ }^{14} \mathrm{C}_{\text {young }}=0.5 \times\left({ }^{14} \mathrm{C}_{\mathrm{CO} 2}+{ }^{14} \mathrm{C}_{\text {rock }}\right.$ ) (Han and Plummer 2016), i.e. half of the ${ }^{14} \mathrm{C}$ of the soil equilibrated $\mathrm{CO}_{2}$, as ${ }^{14} \mathrm{C}_{\text {rock }}$ is 0 pMC. The ${ }^{14} \mathrm{C}$ of the soil equilibrated $\mathrm{CO}_{2}$ can be estimated from the ${ }^{14} \mathrm{C}$ of the atmospheric $\mathrm{CO}_{2}$ (Hua et al. 2013) for the given recharge period based on the ${ }^{3} \mathrm{H}^{3}{ }^{3} \mathrm{He}$ age. By using springs that represent mixtures with variable contribution of the same end-members for the young and old groundwater (e.g. Gugjakovo and Karši Podot in this case), the $\delta^{13} \mathrm{C}$ of the young component can be calculated from the linear regression of their $\delta^{13} \mathrm{C}$ and ${ }^{14} \mathrm{C}$ values $\left({ }^{14} \mathrm{C}=a+b \times \delta{ }^{13} \mathrm{C}\right)$ and the known ${ }^{14} \mathrm{C}$ value for the young component (i.e. $\delta^{13} \mathrm{C}_{\text {young }}=\left({ }^{14} \mathrm{C}_{\text {young }}-a\right) / b$; Fig. 6). The carbon isotope composition $\left(\delta^{13} \mathrm{C}\right.$ and $\left.{ }^{14} \mathrm{C}\right)$ of the old groundwater can then be calculated from the composition of one of the springs and the young groundwater by using a binary mixing model $\left[\mathrm{C}_{\text {mix }}=\right.$ $\left.f_{\text {young }} \times \mathrm{C}_{\text {young }}+\left(1-f_{\text {young }}\right) \times \mathrm{C}_{\text {old }}\right]$ and the fraction of the young component $\left(f_{\text {young }}\right)$ for selected spring estimated from ${ }^{3} \mathrm{H}$ (Fig. 6).

\section{Correction for ${ }^{14} \mathrm{C}$-free dilution of DIC and calculating the age of the old groundwater}

The radiocarbon content of the DIC can be used to estimate the mean residence time of the old groundwater component, assuming that the lowering of DIC ${ }^{14} \mathrm{C}$ content along the groundwater flow-path is only due to ${ }^{14} \mathrm{C}$ decay (half-life of 5,730 years). However, there can be a number of processes and mechanisms along the flow-path (e.g. carbonate rock dissolution, methanogenesis, endogenic $\mathrm{CO}_{2}$, mixing with young groundwater etc.) that can alter the ${ }^{14} \mathrm{C}$ content of DIC, masking the decay signal (Clark 2015; Han and Plummer 2016). In epigene karst groundwater systems, carbonate dissolution is the major modifying factor, diluting the soil ${ }^{14} \mathrm{C}$ signature by addition of ${ }^{14} \mathrm{C}$-free (dead) carbon, as this is the main process that controls the formation of the system (Ford and Williams 2007). In hypogene karst systems, this can be further complicated by the presence of various endogenic gases, that can contribute dead carbon to the DIC pool, especially $\mathrm{CO}_{2}$ of metamorphic or magmatic origin (e.g. Bayari et al. 2009a; Clark et al. 1989). To correct for the ${ }^{14} \mathrm{C}$ dilution, a number of methods and approaches have been developed (see Han and Plummer 2016 for a recent review). Most of them are based on the mass balance of DIC carbon species or carbon isotopes and determine a radiocarbon dilution factor $q$, that represents the fraction of the initial ${ }^{14} \mathrm{C}$ at recharge (e.g. Ingerson and Pearson 1964; Tamers 1975; Fontes and Garnier 1979; Mook 1980). Their applicability is constrained by the assumed chemical reactions and isotopic fractionation along the evolution of the DIC carbon composition (Han and Plummer 2016). Some of them are based on a statistical approach and rely on the use of a larger number of samples from the same groundwater system (e.g. Gonfiantini and Zuppi 2003), or they apply geochemical modeling for the evolution of ${ }^{14} \mathrm{C}$ along the flow-path of the groundwater system (e.g. Plummer et al. 1994; Bayari et al. 2009a). Mixing with younger groundwater can further complicate the ${ }^{14} \mathrm{C}$ signal, by contributing DIC with higher ${ }^{14} \mathrm{C}$ content due to the thermonuclear testing in the 1950-1960s; thus, in some studies (e.g. Gonfiantini and Zuppi 2003), groundwater samples that indicate mixing with younger (bomb-peak affected) groundwater, are excluded from the determination of the ${ }^{14} \mathrm{C}$-based mean residence time. However, sometimes the mixed groundwater is the only available option, especially when sampling is limited to spring sites, and can still provide valuable information about the groundwater system.

For the selected study area, the DIC ${ }^{14} \mathrm{C}$ was altered by addition of dead-carbon from dissolution of carbonate rocks, 
Fig. 6 Derivation of the young and old groundwater carbon isotope composition based on springs that represent mixtures with variable contribution of the same end-members. Bolded text represents measured or known parameters. See text for further explanation

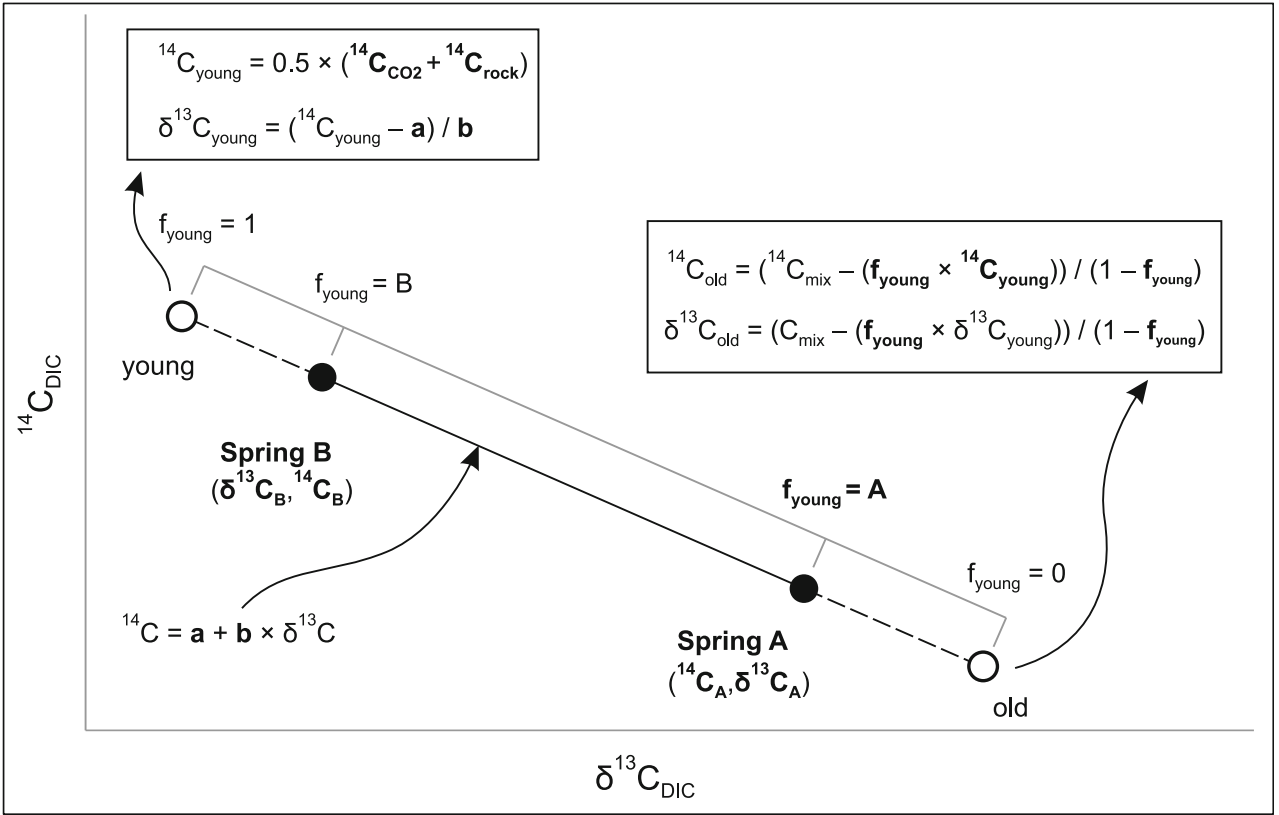

and by endogenic $\mathrm{CO}_{2}$, but also by mixing with younger groundwater (section 'Radiocarbon and the mean residence time of the old groundwater'). To correct for this, the used approach was based on the previously deconvoluted components of carbon derived from dissolution of soil $\mathrm{CO}_{2}$, carbonate rock and endogenic $\mathrm{CO}_{2}$ (section 'Sources of $\mathrm{CO}_{2}$ and deconvolution of carbon components in DIC'). The soil carbon component of the old groundwater $\left(f_{\text {soil-old }}\right)$ can be calculated from the young groundwater fraction $\left(f_{\text {young }}\right)$, given that the endogenic component is provided solely by the old groundwater and the young groundwater has half of the carbon from the bedrock and half from the soil (closed system carbonate dissolution $)$, i.e. $f_{\text {old }}=\left(f_{\text {rock }}-0.5 f_{\text {young }}\right)+\left(f_{\text {soil }}-\right.$ $\left.0.5 f_{\text {young }}\right)+f_{\text {endogenic }}$. The soil fraction in the old groundwater is then calculated from $f_{\text {soil-old }}=\left(f_{\text {soil }}-0.5 f_{\text {young }}\right) / f_{\text {old }}$, and represents a different derivation of the dilution factor $\mathrm{q}$, that also considers contribution of dead carbon from endogenic $\mathrm{CO}_{2}$. The radiocarbon age of the old component (expressed in years) can then be calculated from the decay equation $t=$ $-8267 \times \ln \left[{ }^{14} \mathrm{C}_{\text {old }} /\left(q \times{ }^{14} \mathrm{C}_{0}\right]\right.$, where ${ }^{14} \mathrm{C}_{\text {old }}$ is the old groundwater ${ }^{14} \mathrm{C}$ composition and ${ }^{14} \mathrm{C}_{0}$ is the initial soil ${ }^{14} \mathrm{C}$ at recharge, taken as 100 pMC.

\section{Results}

\section{Chemical characterization of the groundwater}

All studied springs, except for Toplek 4, have relatively stable temperature, electrical conductivity (EC) and $\mathrm{pH}$; these are parameters that were measured more frequently (see the ESM). Melnica and Karši Podot have the highest average temperature $\left(22-23^{\circ} \mathrm{C}\right)$, well above the mean annual air temperature (MAAT) for the area $\left(11-12{ }^{\circ} \mathrm{C}\right.$; Temovski 2016), with Gugjakovo somewhat cooler $\left(17.5^{\circ} \mathrm{C}\right)$ but still above MAAT. Manastir also appears slightly above MAAT $\left(14.2{ }^{\circ} \mathrm{C}\right)$, whereas Toplek 4 is the coldest $\left(7.1^{\circ} \mathrm{C}\right)$ and Toplek 2 has similar temperature $\left(21^{\circ} \mathrm{C}\right)$ to Karši Podot and Melnica. Average $\mathrm{pH}$ values range from $\sim 6.5$ at Karši Podot and Melnica, to near neutral at Gugjakovo (6.9), Manastir (7.1) and Toplek 2 (7.3), and are highest at Toplek 4 (8.3).

All of them have similar chemical composition $\left(\mathrm{Ca}-\mathrm{HCO}_{3}\right.$ type; Fig. 7), with typical karst water major-ion concentrations $\left(\mathrm{Ca}^{2+}>\mathrm{Mg}^{2+}>\mathrm{Na}^{+}>\mathrm{K}^{+}\right.$, and $\left.\mathrm{HCO}_{3}{ }^{-}>\mathrm{SO}_{4}{ }^{2-}>\mathrm{Cl}^{-}\right)$. Only Toplek 2 has somewhat higher $\mathrm{SO}_{4}$ concentrations (Table 1). EC values range from $144 \mu \mathrm{S} / \mathrm{cm}$ at Toplek 4 to $\sim 1,000 \mu \mathrm{S} / \mathrm{cm}$ at Melnica. The springs have similar major ion composition, with $\mathrm{Ca}^{2+}$ as the most abundant cation (Table 1). Alkalinity ranges from $81.4 \mathrm{mg} / \mathrm{L}$ at Toplek 4 up to $633 \mathrm{mg} / \mathrm{L}$ at Melnica. $\mathrm{Cl}^{-}$(up to $13.2 \mathrm{mg} / \mathrm{L}$ ) and $\mathrm{NO}_{3}{ }^{-}$(up to $13.9 \mathrm{mg} / \mathrm{L}$ ) concentrations are relatively low, with the highest $\mathrm{Cl}^{-}$content at Toplek 2 and the highest $\mathrm{NO}_{3}{ }^{-}$content at Manastir, likely reflecting some local contamination. $\mathrm{SO}_{4}{ }^{2-}$ concentrations range from $3.3 \mathrm{mg} / \mathrm{L}$ (Toplek 4) up to $34.1 \mathrm{mg} / \mathrm{L}$ at Toplek 2. $\mathrm{Ca}^{2+}$ ranges from $18.9 \mathrm{mg} / \mathrm{L}$ at Toplek 4 , up to $157 \mathrm{mg} / \mathrm{L}$ at Melnica and Karši Podot. $\mathrm{Mg}^{2+}$ is highest at Karši Podot $(28 \mathrm{mg} / \mathrm{L})$ and lowest at Manastir $(2.6 \mathrm{mg} / \mathrm{L}) . \mathrm{Na}^{+}$and $\mathrm{K}^{+}$ are in relatively low concentrations.

$\mathrm{HCO}_{3}$ is the dominant DIC component, with higher $\mathrm{CO}_{2}$ concentrations found at Gugjakovo, Karši Podot and Melnica. Calculated $\mathrm{pCO}_{2}$ values at Manastir, Toplek 2 and Toplek 4 are lower than $10^{-1.7}$ atm (Table 2) and within the range for soil derived $\mathrm{CO}_{2}\left(10^{-2.5}\right.$ to $10^{-1.5} \mathrm{~atm}$; Clark 2015). $\mathrm{pCO}_{2}$ at Melnica and Karši Podot $\left(\sim 10^{-0.6} \mathrm{~atm}\right)$ is higher than expected 


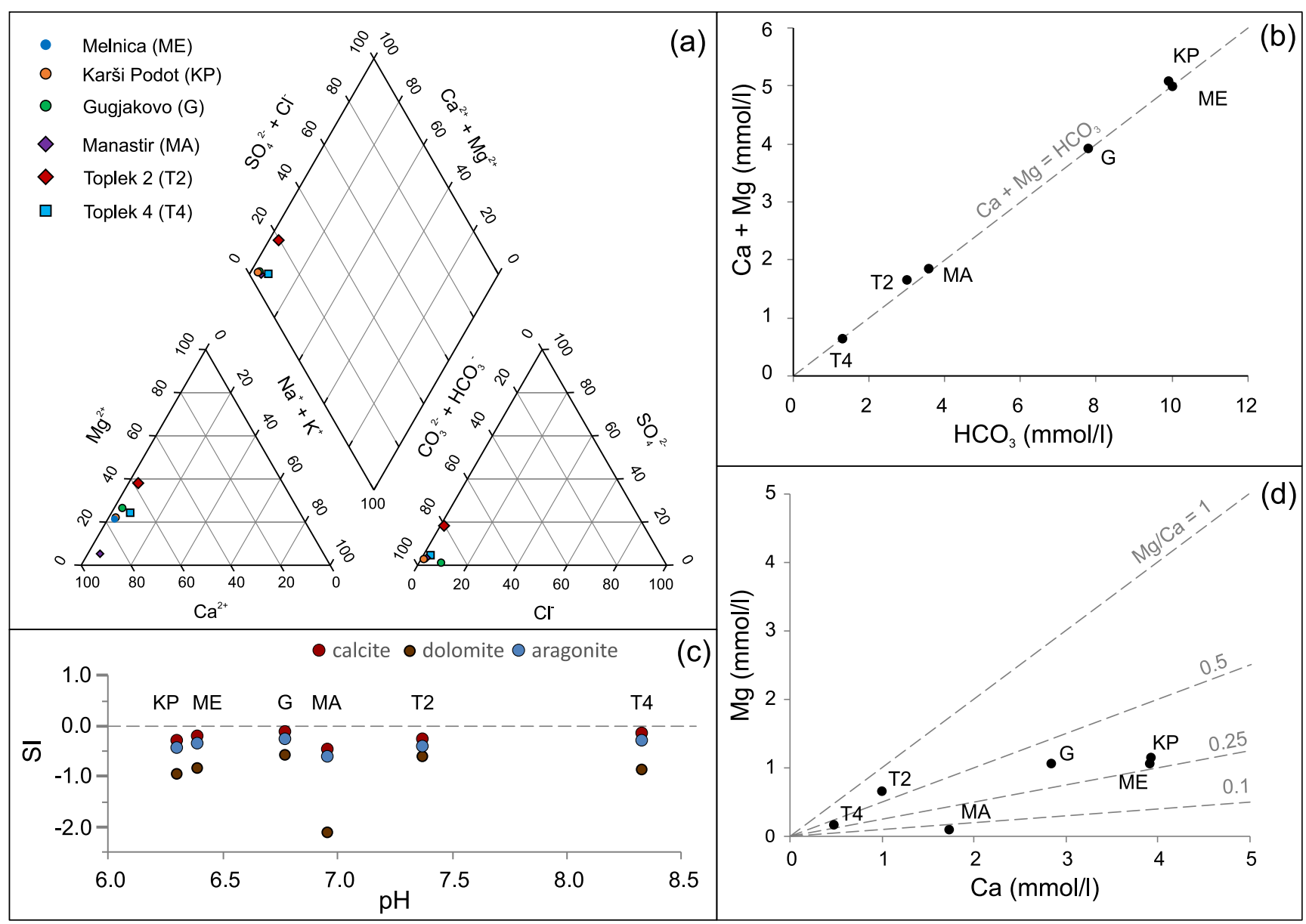

Fig. 7 Chemical composition of the studied springs: a Piper diagram; $\mathbf{b}$ Calcium and magnesium vs bicarbonate; $\mathbf{c}$ carbonate mineral saturation indices; d $\mathrm{Mg} / \mathrm{Ca}$ molar ratio

for soil $\mathrm{CO}_{2}$ indicating a different source for $\mathrm{CO}_{2}$. Gugjakovo has an intermediate value $\left(10^{-1.2} \mathrm{~atm}\right)$ that might also indicate mixing of $\mathrm{CO}_{2}$ from different sources. All of the springs are undersaturated with calcite, aragonite and dolomite, although Gugjakovo, Toplek 4 and Melnica have saturation index (SI) values approaching saturation with calcite (Table 2; Fig. 7). Manastir has the lowest SI values for dolomite, reflecting the travertine aquifer lithology, while Toplek 2 and Gugjakovo have the highest SI values for dolomite, reflecting dominantly interaction with dolomite bedrock.

$\mathrm{Mg} / \mathrm{Ca}$ molar ratios range between 0.06 and 0.66 and indicate dissolution of both dolomite and calcite at all locations, except at Manastir $(\mathrm{Mg} / \mathrm{Ca}=0.06)$, where only calcite dissolution is indicated, reflecting travertine aquifer lithology (Table 2; Fig.7). At Melnica, water discharges from calcite marble, thus the increased $\mathrm{Mg} / \mathrm{Ca}$ ratio (0.27) indicates that

Table 1 Main physical and chemical parameters of the springs. Major ion data are given in $\mathrm{mg} / \mathrm{L}$.

\begin{tabular}{|c|c|c|c|c|c|c|c|c|c|c|c|c|c|}
\hline Spring & Date (m.yyyy) & $\mathrm{T}\left({ }^{\circ} \mathrm{C}\right)$ & $\mathrm{pH}$ & $\mathrm{EC}(\mu \mathrm{S} / \mathrm{cm})$ & $\mathrm{Ca}^{2+}$ & $\mathrm{Mg}^{2+}$ & $\mathrm{Na}^{+}$ & $\mathrm{K}^{+}$ & Alkalinity & $\mathrm{Cl}^{-}$ & $\mathrm{SO}_{4}{ }^{2-}$ & $\mathrm{NO}_{3}^{-}$ & $\mathrm{SiO}_{2}$ \\
\hline Gugjakovo & 9.2018 & 17.6 & 6.8 & 764 & 113.5 & 25.6 & 5.2 & 1.2 & 488.1 & 8.0 & 8.1 & 4.5 & 3.5 \\
\hline Karši Podot & 9.2018 & 23.2 & 6.3 & 934 & 157.4 & 28.0 & 5.4 & 2.2 & 625.4 & 4.0 & 14.0 & 3.4 & 9.6 \\
\hline Melnica & 9.2018 & 22.3 & 6.4 & 961 & 156.6 & 25.9 & 5.5 & 2.1 & 633.0 & 3.8 & 14.9 & 4.4 & 11.3 \\
\hline Manastir & 9.2018 & 14.1 & 7.0 & 408 & 69.4 & 2.6 & 3.4 & 1.2 & 221.5 & 2.5 & 6.6 & 13.9 & 11.9 \\
\hline Toplek 2 & 9.2018 & 21.1 & 7.4 & 362 & 40.1 & 15.9 & 2.3 & 1.0 & 185.3 & 1.6 & 33.3 & 1.3 & - \\
\hline Toplek 2 & 3.2019 & 21.4 & 7.2 & 363 & 42.1 & 16.9 & 2.3 & 1.0 & 166.8 & 13.2 & 34.1 & 9.3 & 9.6 \\
\hline Toplek 4 & 3.2019 & 6.5 & 8.3 & 144 & 18.9 & 4.1 & 1.8 & 0.8 & 81.4 & 1.5 & 3.3 & $<1$ & 6.4 \\
\hline
\end{tabular}


Table 2 DIC species, partial pressure of carbon dioxide $\left(\mathrm{pCO}_{2}\right)$, carbonate mineral saturation indices ( $\left.\mathrm{SI}\right)$, and $\mathrm{Mg} / \mathrm{Ca}$ ratio of the studied springs

\begin{tabular}{lllllllllllll}
\hline Spring & Date (m.yyyy) & $\mathrm{T}\left({ }^{\circ} \mathrm{C}\right)$ & $\mathrm{pH}$ & $\begin{array}{l}\mathrm{DIC} \\
\mathrm{mmol} / \mathrm{L}\end{array}$ & $\mathrm{CO}_{2}$ & $\mathrm{HCO}_{3}$ & $\log \mathrm{pCO}_{2}(\mathrm{~atm})$ & $\mathrm{SI}_{\text {calcite }}$ & $\mathrm{SI}_{\text {aragonite }}$ & $\mathrm{SI}_{\text {dolomite }}$ & $\mathrm{Mg} / \mathrm{Ca}$ \\
\hline Gugjakovo & 9.2018 & 17.6 & 6.8 & 10.7 & 3.0 & 7.8 & -1.15 & -0.10 & -0.25 & -0.59 & 0.38 \\
Karši Podot & 9.2018 & 23.2 & 6.3 & 20.0 & 10.1 & 9.9 & -0.55 & -0.28 & -0.42 & -0.97 & 0.29 \\
Melnica & 9.2018 & 22.3 & 6.4 & 18.5 & 8.4 & 10.0 & -0.64 & -0.20 & -0.34 & -0.85 & 0.27 \\
Manastir & 9.2018 & 14.1 & 7.0 & 4.5 & 1.0 & 3.6 & -1.69 & -0.44 & -0.59 & -2.12 & 0.06 \\
Toplek 2 & 9.2018 & 21.1 & 7.4 & 3.3 & 0.3 & 3.0 & -2.13 & -0.25 & -0.40 & -0.60 & 0.65 \\
Toplek 2 & 3.2019 & 21.4 & 7.2 & 3.0 & 0.4 & 2.7 & -2.03 & -0.42 & -0.57 & -0.94 & 0.66 \\
Toplek 4 & 3.2019 & 6.5 & 8.3 & 1.3 & 0.0 & 1.3 & -3.52 & -0.13 & -0.29 & -0.88 & 0.36 \\
\hline
\end{tabular}

at depth water likely circulates either within or at least at the contact with dolomite. Karši Podot is discharging from dolomite marble, but has similar $\mathrm{Mg} / \mathrm{Ca}$ ratio (0.29) compared to Melnica, indicating either preferable calcite dissolution, or also circulation through calcite marble at depth. A higher $\mathrm{Mg} / \mathrm{Ca}$ ratio at Gugjakovo Springs indicates dissolution of dolomite marble. The $\mathrm{Mg} / \mathrm{Ca}$ ratios of Toplek $2(\sim 0.66)$ and Toplek 4 (0.36) reflect their dolomite aquifers lithology, with higher $\mathrm{Mg} / \mathrm{Ca}$ ratios at Toplek 2 likely reflecting the longer water-rock interaction.

The studied springs have higher concentrations of certain trace elements (TE), of which boron, strontium, arsenic, and lithium are the most abundant (Table 3; ESM). Melnica and Karši Podot have similar TE compositions, with Melnica having slightly higher concentrations. Gugjakovo also has similar composition to Melnica and Karši Podot but with much lower concentrations. Boron concentrations are highest at Melnica (705 $\mu \mathrm{g} / \mathrm{L})$, Karši Podot (462 $\mu \mathrm{g} / \mathrm{L})$ and Gugjakovo, and are much lower $(<15 \mu \mathrm{g} / \mathrm{L})$ at the other springs. Arsenic is highest at Toplek $2(414 \mu \mathrm{g} / \mathrm{L})$, but Melnica $(209 \mu \mathrm{g} / \mathrm{L})$ and Karši Podot $(149 \mu \mathrm{g} / \mathrm{L})$ have also high concentrations. High arsenic concentrations have been reported previously for Toplek 2 (Boev and Lepitkova 2003; Boev and Jančev 2014). Toplek 2 is located next to the Allchar As-Sb-Tl-rich ore deposit (Palinkaš et al. 2018), where the trace element composition was attributed to higher water-rock interaction with the volcanic rocks of the Kožuf-Kozjak volcanism. Lithium is increased at Melnica, Karši Podot and Gugjakovo (35-
$51 \mu \mathrm{g} / \mathrm{L})$, with much lower concentrations $(<3 \mu \mathrm{g} / \mathrm{L})$ found at the other springs. Higher concentrations of boron and lithium found at Melnica, Karši Podot and Gugjakovo, but not at the Toplek springs, might be due to contact at depth with the granitoid plutons of the Pelagonian massif. Strontium is generally increased at all springs, except Toplek 4, with concentrations ranging from 82 to $348 \mu \mathrm{g} / \mathrm{L}$, and Melnica having highest concentration.

Pearson's correlation coefficients of the physico-chemical parameters show several highly correlated parameters (Table 4; ESM), which reflect water-rock interactions with three main aquifer lithologies. $\mathrm{HCO}_{3}, \mathrm{Ca}$, and $\mathrm{Mg}$ are reflecting the dominant dissolution of carbonate rocks. $\mathrm{Na}$ and $\mathrm{K}$ likely reflect water-rock interactions with the various schist formations or the Pelagonian metamorphic basement. Strong correlation of $\mathrm{B}, \mathrm{U}, \mathrm{Cs}, \mathrm{Rb}$ and $\mathrm{Sr}$ points to contact with the granitoid bodies within the Pelagonian basement. The highly correlated $\mathrm{As}, \mathrm{Mo}, \mathrm{Sb}$ and $\mathrm{Tl}$ clearly reflect contact with the Kožuf-Kozjak volcanic complex or ore deposits related with earlier hydrothermal system connected to the volcanism.

This is further illustrated by the hierarchical cluster analysis (HCA) which reflects the similarities between the studied groundwater (Fig. 8). The clustering of the chemical parameters reveals distinct groups, and in addition to the circulation through the carbonate formations, indicates also interaction with rocks from the Pelagonian basement, and rocks of the Neogene-Quaternary Kožuf-Kozjak volcanic complex.
Table 3 Concentrations of selected trace elements $(\mu \mathrm{g} / \mathrm{L})$. The complete trace element data are given in the ESM

\begin{tabular}{lllrlrlllllll}
\hline Spring & Date (m.yyyy) & $\mathrm{B}$ & $\mathrm{Cs}$ & $\mathrm{U}$ & $\mathrm{Rb}$ & $\mathrm{Sr}$ & $\mathrm{Li}$ & $\mathrm{As}$ & $\mathrm{Sb}$ & $\mathrm{Mo}$ & $\mathrm{Tl}$ \\
\hline Gugjakovo & 9.2018 & 217 & 3.1 & 0.9 & 7.5 & 172 & 50.9 & 32 & 0.08 & 0.15 & 0.02 \\
Karši Podot & 9.2018 & 462 & 7.8 & 1.7 & 10.1 & 344 & 34.7 & 149 & 3.45 & 1.25 & 0.08 \\
Melnica & 9.2018 & 705 & 10.1 & 1.8 & 11.6 & 348 & 41.9 & 209 & 3.36 & 1.66 & 0.11 \\
Manastir & 9.2018 & 15 & 7.1 & 1.1 & 6.5 & 233 & 3.3 & 11 & 0.15 & 0.36 & 0.00 \\
Toplek 2 & 9.2018 & 14 & 2.9 & 0.7 & 4.2 & 192 & 3.1 & 414 & 15.54 & 1.75 & 0.87 \\
Toplek 4 & 3.2019 & $<4$ & 0.4 & 0.1 & 0.9 & 82 & 0.8 & 6 & 0.14 & 0.19 & 0.04 \\
\hline
\end{tabular}


Table 4 Pearson's correlation coefficients of selected physico-chemical parameters. The complete correlation data of all parameters are given in the ESM

\begin{tabular}{|c|c|c|c|c|c|c|c|c|c|c|c|c|c|c|}
\hline & $\mathrm{HCO}_{3}$ & $\mathrm{Ca}$ & $\mathrm{Mg}$ & $\mathrm{Na}$ & $\mathrm{K}$ & B & Cs & $\mathrm{U}$ & $\mathrm{Rb}$ & $\mathrm{Sr}$ & As & Mo & $\mathrm{Sb}$ & $\mathrm{Tl}$ \\
\hline $\mathrm{HCO}_{3}$ & 1 & & & & & & & & & & & & & \\
\hline $\mathrm{Ca}$ & $0.99^{\mathrm{a}}$ & 1 & & & & & & & & & & & & \\
\hline $\mathrm{Mg}$ & $0.89^{\mathrm{b}}$ & $0.83^{\mathrm{b}}$ & 1 & & & & & & & & & & & \\
\hline $\mathrm{Na}$ & $0.97^{\mathrm{a}}$ & $0.97^{\mathrm{a}}$ & $0.82^{\mathrm{b}}$ & 1 & & & & & & & & & & \\
\hline $\mathrm{K}$ & $0.89^{\mathrm{b}}$ & $0.92^{\mathrm{a}}$ & 0.69 & $0.82^{\mathrm{b}}$ & 1 & & & & & & & & & \\
\hline B & 0.10 & 0.21 & -0.19 & 0.24 & 0.20 & 1 & & & & & & & & \\
\hline Cs & 0.46 & 0.56 & 0.10 & 0.51 & 0.64 & 0.78 & 1 & & & & & & & \\
\hline $\mathrm{U}$ & 0.50 & 0.60 & 0.22 & 0.56 & 0.63 & $0.84^{\mathrm{b}}$ & $0.96^{\mathrm{a}}$ & 1 & & & & & & \\
\hline $\mathrm{Rb}$ & 0.50 & 0.59 & 0.23 & 0.61 & 0.52 & $0.88^{\mathrm{b}}$ & $0.90^{\mathrm{b}}$ & $0.97^{\mathrm{a}}$ & 1 & & & & & \\
\hline $\mathrm{Sr}$ & 0.45 & 0.54 & 0.17 & 0.48 & 0.62 & $0.82^{\mathrm{b}}$ & $0.95^{\mathrm{a}}$ & $0.99^{\mathrm{a}}$ & $0.93^{\mathrm{a}}$ & 1 & & & & \\
\hline As & -0.35 & -0.34 & -0.17 & -0.41 & -0.23 & 0.15 & 0.13 & 0.21 & 0.12 & 0.30 & 1 & & & \\
\hline Mo & -0.23 & -0.17 & -0.24 & -0.26 & 0.00 & 0.50 & 0.49 & 0.54 & 0.43 & 0.63 & $0.90^{\mathrm{b}}$ & 1 & & \\
\hline $\mathrm{Sb}$ & -0.35 & -0.38 & -0.08 & -0.45 & -0.27 & -0.13 & -0.10 & -0.03 & -0.12 & 0.07 & $0.96^{\mathrm{a}}$ & 0.76 & 1 & \\
\hline $\mathrm{Tl}$ & -0.42 & -0.46 & -0.11 & -0.52 & -0.37 & -0.28 & -0.25 & -0.19 & -0.27 & -0.10 & $0.90^{\mathrm{b}}$ & 0.65 & $0.98^{\mathrm{a}}$ & 1 \\
\hline
\end{tabular}

${ }^{\text {a }}$ Correlations significant at 0.01 level

${ }^{\mathrm{b}}$ Correlations significant at 0.05 level

\section{Water stable isotope composition}

Water stable isotope composition was measured more frequently and the springs showed relatively small variation in $\delta^{18} \mathrm{O}$ and $\delta^{2} \mathrm{H}$ with values that fall near the local and global meteoric water lines (Fig. 9; ESM). From the main studied springs, Gugjakovo, Karši Podot and Melnica have similar values, of which Gugjakovo has the lowest $\left(-10.4 \pm 0.5 \% \circ \delta^{18} \mathrm{O},-72.2 \pm\right.$ $\left.2.5 \% \circ \delta^{2} \mathrm{H}\right)$ and Karši Podot $\left(-10.1 \pm 0.3 \% \circ \delta^{18} \mathrm{O},-70.0 \pm\right.$ $\left.2.1 \% \circ \delta^{2} \mathrm{H}\right)$ and Melnica $\left(-10.0 \pm 0.3 \% \circ \delta^{18} \mathrm{O},-66.9 \pm 1.5 \%\right.$ 。 $\left.\delta^{2} \mathrm{H}\right)$ have slightly higher values. Manastir has more positive values then them $\left(-9.2 \pm 0.4 \%\right.$ o $\delta^{18} \mathrm{O},-65.4 \pm 1.1 \%$ o $\left.\delta^{2} \mathrm{H}\right)$, while Toplek $2\left(-9.9 \pm 0.2 \% \circ \delta^{18} \mathrm{O},-63.6 \pm 1.3 \% \circ \delta^{2} \mathrm{H}\right)$ and Toplek $4\left(-10.6 \pm 1.1 \% \circ \delta^{18} \mathrm{O},-69.5 \pm 7.3 \% \circ \delta^{2} \mathrm{H}\right)$ located further east, have similar composition, with Toplek 4 having high variability and reflecting recent recharge and fast circulation.

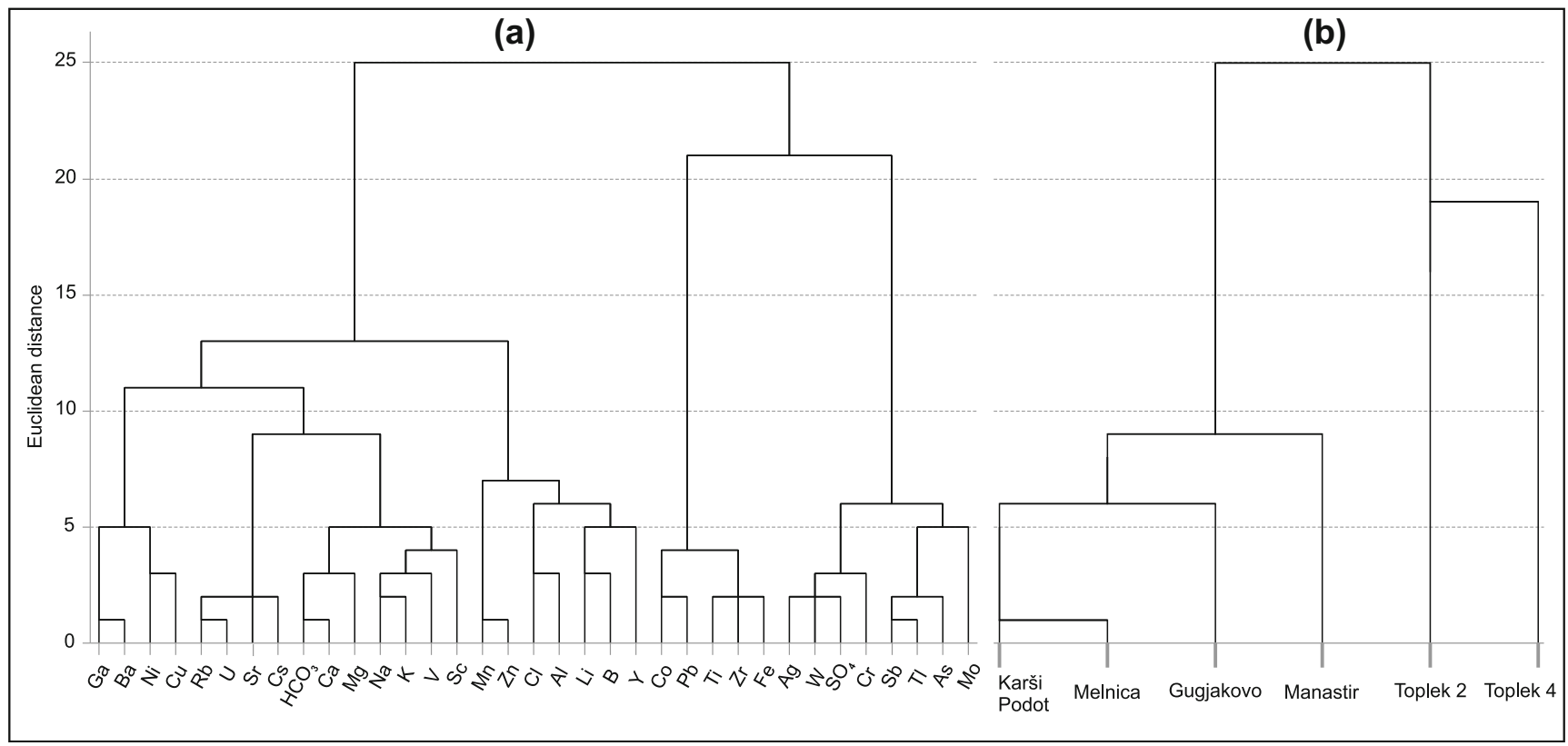

Fig. 8 Hierarchical cluster analyses of the studied groundwater with Ward's method using major ions and trace elements, based on: a chemical parameters; b springs 
Fig. 9 Water stable isotope composition of the springs. Sample codes same as in Fig. 7

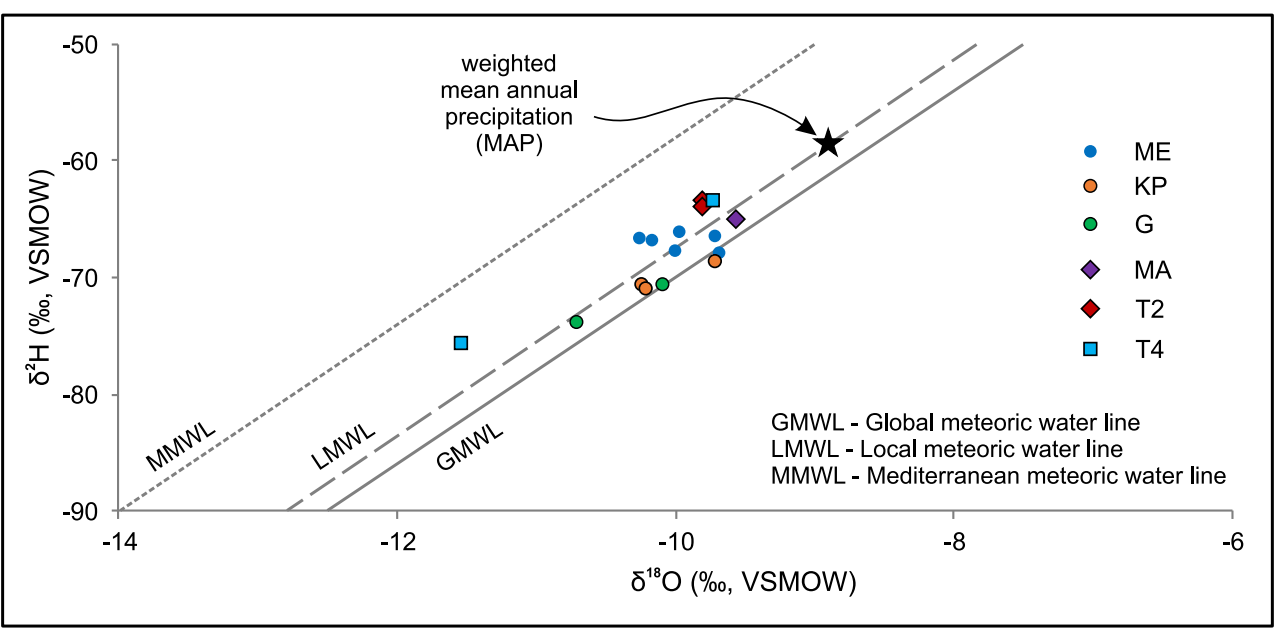

They all have lower values compared to the recently measured values for the mean annual composition of the local precipitation (MAP; $-8.9 \% \circ \delta^{18} \mathrm{O}$ and $-58.5 \% \circ \delta^{2} \mathrm{H}$; M. Temovski, Institute for Nuclear Research, Debrecen, unpublished data; Fig. 9). This can be a result of dominant recharge of the aquifers during the cooler period of the year or higher contribution from water infiltrated at higher elevation, or, for the older groundwater, it might indicate recharge under cooler climate conditions.

\section{Stable isotope composition of the dissolved sulfate}

The sulfur stable isotope composition of the dissolved $\mathrm{SO}_{4}{ }^{2-}$ was analysed with attempts also to measure the oxygen stable isotopes. Melnica and Karši Podot had similar values for $\delta^{34} \mathrm{~S}$ $(-1.3$ and $-1.4 \%)$, Toplek 2 had lowest values $(-4.0 \%)$, while positive $\delta^{34} \mathrm{~S}$ values were found at Manastir $(+2.1 \%$ o $)$ and Gugjakovo $(+5.1 \% o) . \delta^{18} \mathrm{O}$ values were positive and ranged from $+0.2 \%$ at Toplek 2 up to $+5.6 \%$ at Karši Podot (Table 5). The sulfate stable isotopes at Melnica, Karši Podot and Toplek 2 are within the range of values $(-7.5$ to $+0.7 \%$ o $\delta^{34} \mathrm{~S} ;-3.9$ to $+8.2 \% \circ \delta^{18} \mathrm{O}$ ) found in the gypsum deposits of Provalata Cave (Temovski et al. 2018), whose origin is attributed to oxidation of $\mathrm{H}_{2} \mathrm{~S}$ in vadose settings (i.e. sulfuric acid speleogenesis by condensation corrosion). Their $\delta^{34} \mathrm{~S}$ values

Table 5 Stable isotope composition of the dissolved sulfate

\begin{tabular}{lll}
\hline Spring & $\delta^{34} \mathrm{~S}(\%, \mathrm{VCDT})$ & $\delta^{18} \mathrm{O}(\%, \mathrm{VSMOW})$ \\
\hline Gugjakovo & +5.1 & +4.0 \\
Karši Podot & -1.6 & +5.6 \\
Melnica & -1.4 & +5.5 \\
Manastir & +2.1 & +3.5 \\
Toplek 2 & -4.0 & +0.2 \\
Toplek 4 & - & - \\
\hline
\end{tabular}

are also within the range ( -9.8 to $0.9 \%$ ) of the sulfide minerals found in Allchar ore deposit, where contribution of magmatic $\mathrm{H}_{2} \mathrm{~S}$ was identified for the main mineralization stage (Palinkaš et al. 2018). The source of the dissolved sulfate at these springs, thus can be attributed to oxidation of deepseated sulfides (either $\mathrm{H}_{2} \mathrm{~S}$ or sulfide minerals deposited by earlier hydrothermal systems). The values at Gugjakovo and Manastir indicate a different source, likely oxidation of sedimentary pyrite.

\section{Stable isotope composition of DIC and the source of $\mathrm{CO}_{2}$}

The $\delta^{13} \mathrm{C}_{\text {DIC }}$ showed clear differences between the springs (Table 6), with Melnica $(-0.93 \%$ ) and Karši Podot $(-1.95 \%$ o having the highest values, Gugjakovo $(-7.34 \%$ o and Toplek $2(-7.87 \%$ ) somewhat intermediate, and lowest values found at Manastir (-9.63\%o) and Toplek $4(-9.25 \%$ ).

The $\mathrm{pCO}_{2}$, $\mathrm{pH}$ and $\delta^{13} \mathrm{C}_{\mathrm{DIC}}$ at Manastir and Toplek 2 indicate DIC evolution by carbonate dissolution mostly under closed system conditions after some initial open system dissolution. The very low $\mathrm{pCO}_{2}\left(10^{-3.5} \mathrm{~atm}\right)$, high $\mathrm{pH}$ and low alkalinity at Toplek 4 indicate closed system carbonate dissolution. The high $\mathrm{pCO}_{2}$, low $\mathrm{pH}$ and high $\delta^{13} \mathrm{C}$ at Melnica and Karši Podot indicate a possible contribution of endogenic $\mathrm{CO}_{2}$.

The obtained values for $\delta^{13} \mathrm{C}_{\text {ext }}$ range from -20.8 to $-2.3 \%$ o (Table 6). Values reflecting soil $\delta^{13} \mathrm{C}_{\mathrm{CO} 2}$ are found at Manastir and Toplek $4\left(-20.1 \pm 0.7 \%\right.$ ), reflecting the dominantly $\mathrm{C}_{3}$ vegetation of the area (mostly covered by forests), and the others show variable contribution of endogenic $\mathrm{CO}_{2}$. To estimate the $\delta^{13} \mathrm{C}$ of the endogenic $\mathrm{CO}_{2}$, the mixing of a soil endmember with $\delta^{13} \mathrm{C}$ of $-20.1 \%$ and a range of $0.5-5 \mathrm{mmol} / \mathrm{L}$ for $\mathrm{C}_{\mathrm{ext}}$, with an endogenic end-member was modeled (Fig. 6). The $\mathrm{C}_{\text {ext }}$ and $\delta^{13} \mathrm{C}_{\text {ext }}$ values of Karši Podot and Gugjakovo were used to constrain the $\delta^{13} \mathrm{C}$ of the endogenic end-member, as their close proximity and similar geochemical composition indicate that they share the same end-members. The closest 
Table 6 Sources and stable isotopic composition of carbon. $\mathrm{C}_{\text {rock }}$ stands for carbon obtained by dissolution of carbonate rocks, and $\mathrm{C}_{\mathrm{ext}}$ for carbon from endogenic and soil $\mathrm{CO}_{2}$

\begin{tabular}{|c|c|c|c|c|c|c|c|c|}
\hline \multirow[t]{2}{*}{ Spring } & $\mathrm{C}_{\text {rock }}$ & $\mathrm{C}_{\mathrm{ext}}$ & $\delta^{13} \mathrm{C}_{\mathrm{DIC}}$ & \multirow[t]{2}{*}{$\delta^{13} \mathrm{C}_{\text {rock }}$} & \multirow[t]{2}{*}{$\delta^{13} \mathrm{C}_{\mathrm{ext}}$} & \multirow{2}{*}{$\begin{array}{c}\mathrm{C}_{\text {rock }} \\
\%\end{array}$} & \multicolumn{2}{|c|}{ Sources of $C_{e x t}$} \\
\hline & $\mathrm{mmol} / \mathrm{L}$ & & $\%$, VPDB & & & & - Soil $\mathrm{CO}_{2}$ & Endogenic $\mathrm{CO}_{2}$ \\
\hline Gugjakovo & 3.8 & 6.9 & -7.34 & +2.8 & -12.9 & 35.5 & 45.7 & 18.8 \\
\hline Karši Podot & 4.9 & 15.1 & -1.95 & +2.8 & -3.5 & 24.7 & 24.6 & 50.8 \\
\hline Melnica & 4.8 & 13.6 & -0.93 & +2.8 & -2.3 & 26.1 & 20.3 & 53.5 \\
\hline Manastir & 1.8 & 2.8 & -9.63 & +7.9 & -20.8 & 39.0 & 61.0 & 0.0 \\
\hline Toplek 2 & 1.3 & 1.3 & -7.87 & +2.7 & -15.0 & 40.1 & 47.4 & 12.5 \\
\hline Toplek 4 & 0.6 & 0.6 & -9.25 & +2.7 & -19.4 & 45.9 & 54.1 & 0.0 \\
\hline
\end{tabular}

match was found for a mixing line defined by soil $\mathrm{CO}_{2}$ with $\delta^{13} \mathrm{C}$ of $-20.1 \%$ and $\mathrm{C}_{\text {ext }}$ of $4.9 \mathrm{mmol} / \mathrm{L}$ to an endogenic endmember with $\delta^{13} \mathrm{C}$ value of $+4.5 \%$ (Fig. 10 ). Such $\delta^{13} \mathrm{C}$ value indicates a metamorphic origin for the endogenic $\mathrm{CO}_{2}$ component (Chiodini et al. 2000; Clark 2015). However, based on the noble gas data (section 'Noble gases, tritium and the mean residence time of the young groundwater'), there is some contribution of mantle helium, indicating also possible contribution of mantle $\mathrm{CO}_{2}$, thus the metamorphic $\mathrm{CO}_{2} \delta^{13} \mathrm{C}$ might be somewhat underestimated. Based on the three identified sources of carbon (carbonate rock, soil $\mathrm{CO}_{2}$ and endogenic $\mathrm{CO}_{2}$ ), the fractions of endogenic $\mathrm{CO}_{2}$ range from $13 \%$ at Toplek 2 and $19 \%$ at Gugjakovo, to 51 and $54 \%$ at Karši Podot and Melnica, respectively.

\section{Noble gases, tritium and the mean residence time of the young groundwater}

Noble gas concentrations are close to air-equilibrated values, except for He concentrations, which are somewhat higher at
Melnica, and much higher at Gugjakovo (Table 7). The $R / R_{\mathrm{a}}$ ratios (where $R$ and $R_{\mathrm{a}}$ are the ${ }^{3} \mathrm{He} /{ }^{4} \mathrm{He}$ ratio of the sample and air, respectively), range between 0.76 and 1.16 , with Toplek 4 reflecting air composition $\left(R / R_{\mathrm{a}} \approx 1\right)$, and the others having $R /$ $R_{\mathrm{a}}$ values either lower or higher than 1 .

The NGT values range from 3.8 to $22.7^{\circ} \mathrm{C}$ (Table 7). The estimated NGT for Manastir $\left(11.8^{\circ} \mathrm{C}\right)$ is within the range of MAAT for the area (Fig. 11a). The NGTs for Gugjakovo, Toplek 2 and Toplek 4 are somewhat lower than expected for the local MAAT at the spring sites, which might be due to different reasons such as infiltration during older cooler periods, larger contribution of water infiltrated at higher elevation, or fast and/or higher contribution from water infiltrated during the winter period. The coldest estimated NGT at Toplek $4\left(3.8^{\circ} \mathrm{C}\right)$, clearly reflects winter infiltration, also confirmed by the low spring water temperature, and the recent ${ }^{3} \mathrm{H}-{ }^{3} \mathrm{He}$ age. Their $\delta^{18} \mathrm{O}$ and NGT values follow the relationship of local mean monthly temperatures and monthly precipitation $\delta^{18} \mathrm{O}$ (as observed during 2018-2019; Fig. 11b), which might be a result of higher contribution of winter infiltration.
Fig. 10 a Plot of the amount $\left(\mathrm{C}_{\mathrm{ext}}\right)$ and isotopic composition $\left(\delta^{13} \mathrm{C}_{\text {ext }}\right)$ of dissolved carbon from sources other than carbonate dissolution, with studied springs showing variable contribution of endogenic $\mathrm{CO}_{2}\left(\delta^{13} \mathrm{C}\right.$ of $+4.5 \%$ ) to soil $\mathrm{CO}_{2}\left(\delta^{13} \mathrm{C}\right.$ of $\left.-20.1 \% o\right)$.

The open circles represent springs with only soil derived $\mathrm{CO}_{2}$. b The ternary diagram showing the calculated percentages of carbon sourced from dissolution of carbonates $\left(\mathrm{C}_{\text {rock }}\right)$, soil $\mathrm{CO}_{2}$ $\left(\mathrm{C}_{\text {soii }}\right)$ and endogenic $\mathrm{CO}_{2}$ $\left(\mathrm{C}_{\text {endo }}\right)$. Sample codes same as in Fig. 7

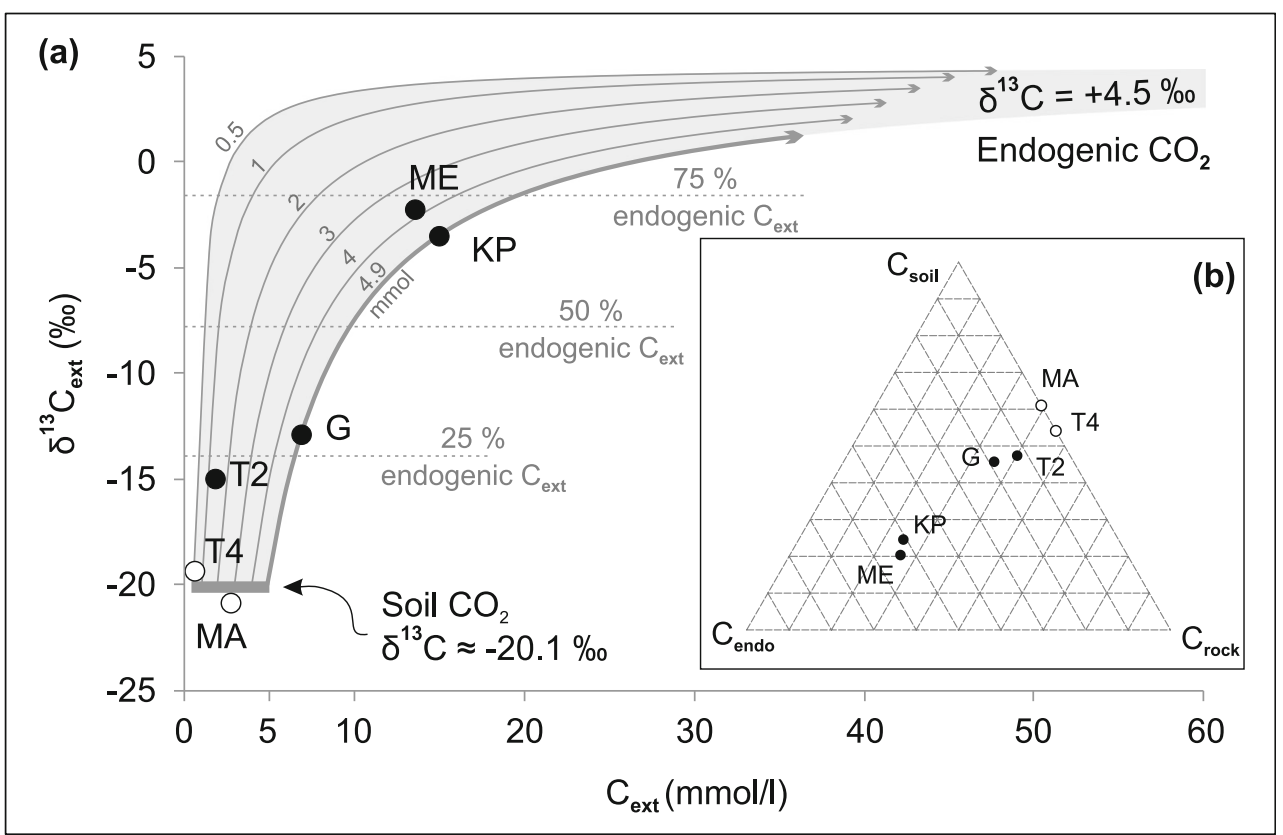


Table 7 Noble gas concentrations $\left(\mathrm{cm}^{3} \mathrm{STP} / \mathrm{g}\right)$, helium isotope ratios and noble gas recharge temperatures (NGT). $R_{\mathrm{c}} / R_{\mathrm{a}}$ is the entrapped air- and tritiogenic ${ }^{3} \mathrm{He}$ - corrected ratio

\begin{tabular}{|c|c|c|c|c|c|c|c|c|c|c|c|c|c|}
\hline Spring & $\mathrm{He}^{\mathrm{a}}$ & $\mathrm{Ne}^{\mathrm{b}}$ & $\mathrm{Ar}^{\mathrm{c}}$ & $\mathrm{Kr}^{\mathrm{a}}$ & $\mathrm{Xe}^{\mathrm{a}}$ & $\begin{array}{l}R / \\
R_{\mathrm{a}}\end{array}$ & $\begin{array}{l}R_{\mathrm{c}} / \\
R_{\mathrm{a}}\end{array}$ & ${ }^{4} \mathrm{He} /{ }^{20} \mathrm{Ne}$ & $\begin{array}{l}\text { Atmospheric } \\
\mathrm{He}(\%)\end{array}$ & $\begin{array}{l}\text { Mantle } \\
\mathrm{He}(\%)\end{array}$ & $\begin{array}{l}\text { Crustal } \\
\mathrm{He}(\%)\end{array}$ & $\begin{array}{l}\text { Mean } \\
\text { recharge } \\
\text { elevation } \\
\text { (m) }\end{array}$ & $\begin{array}{l}\text { NGT } \\
\left({ }^{\circ} \mathrm{C}\right)\end{array}$ \\
\hline Gugjakovo & 891.5 & 2.0 & 4.0 & 8.8 & 1.2 & 0.76 & 0.74 & 48.5 & 0.5 & 9 & 91 & 1,181 & 9.7 \\
\hline $\begin{array}{l}\text { Karši } \\
\text { Podot }\end{array}$ & 5.7 & 1.3 & 2.5 & 5.6 & 0.8 & 0.89 & 0.67 & 0.5 & 53 & 2 & 46 & 1,181 & 22.7 \\
\hline Melnica & 47.2 & 1.6 & 2.5 & 5.8 & 0.8 & 1.14 & 0.88 & 3.4 & 7 & 10 & 83 & 1,275 & 20.0 \\
\hline Manastir & 6.2 & 2.0 & 3.4 & 7.9 & 1.1 & 0.80 & 0.73 & 0.3 & 71 & 0 & 29 & 814 & 11.8 \\
\hline Toplek 2 & 9.4 & 2.1 & 3.7 & 8.7 & 1.3 & 1.16 & 0.48 & 0.5 & 49 & 0 & 51 & 911 & 8.2 \\
\hline Toplek 4 & 4.8 & 2.1 & 4.1 & 9.9 & 1.5 & 0.98 & 0.97 & 0.2 & 100 & 0 & 0 & 911 & 3.8 \\
\hline
\end{tabular}

$\mathrm{a} \times 10^{-8}$

$\mathrm{b} \times 10^{-7}$

c $\times 10^{-4}$

The estimated NGTs for Karši Podot and Melnica are much higher and clearly reflect the temperature of the groundwater at the spring (Fig. 11a). At Karši Podot, this is probably due to re-equilibration of the dissolved noble gases to the cave atmosphere behind the point where the water emerges at the cave wall. Considering the sponge-like morphology of the cave (Temovski 2016), there is likely a large contact of air with the water table along many small interconnected cavities. Similarly, at Melnica, a close match of the NGT to the spring water temperature might indicate an existence of a cave passage behind the spring where the water table is in contact with a large cave air mass.

${ }^{3} \mathrm{H}$ was found in all of the springs and ranged from 1.5 to 5.8 TU. Karši Podot (1.5 TU) and Melnica (1.7 TU) have the lowest values, Toplek 2 (2.3 TU) and Manastir (2.7 TU) intermediate, and Gugjakovo (3.4 TU) and Toplek 4 (5.8 TU) had the highest ${ }^{3} \mathrm{H}$ values. Assuming no mantle helium, and after removal of air-derived and terrigenic (crustal) $\mathrm{He}$, the calculated concentrations of ${ }^{3} \mathrm{He}$ formed by ${ }^{3} \mathrm{H}$ decay $\left({ }^{3} \mathrm{He}_{\text {trit }}\right)$, except for Melnica and Gugjakovo, range from 0 to $8.3 \times 10^{-14} \mathrm{~cm}^{3} \mathrm{STP} / \mathrm{g}$, yielding ${ }^{3} \mathrm{H}^{-}{ }^{3} \mathrm{He}$ apparent ages of $0 \pm$ 3 years for Toplek $4,10 \pm 3$ years for Manastir, $31 \pm 2$ years for Karši Podot, and $49 \pm 1$ years for Toplek 2 . The calculated ${ }^{3} \mathrm{He}_{\text {trit }}$ concentrations were much higher at Melnica $(68 \times$ $\left.10^{-14} \mathrm{~cm}^{3} \mathrm{STP} / \mathrm{g}\right)$ and especially at Gugjakovo (909 $\times$ $10^{-14} \mathrm{~cm}^{3} \mathrm{STP} / \mathrm{g}$ ), indicating presence of mantle derived ${ }^{3} \mathrm{He}$, thus no ${ }^{3} \mathrm{H}-{ }^{3} \mathrm{He}$ apparent ages were calculated.

The possible mantle helium contribution can be estimated from a three-component (atmospheric, crustal and mantle helium) mixing model, using $R / R_{\mathrm{a}}$ values corrected for excess

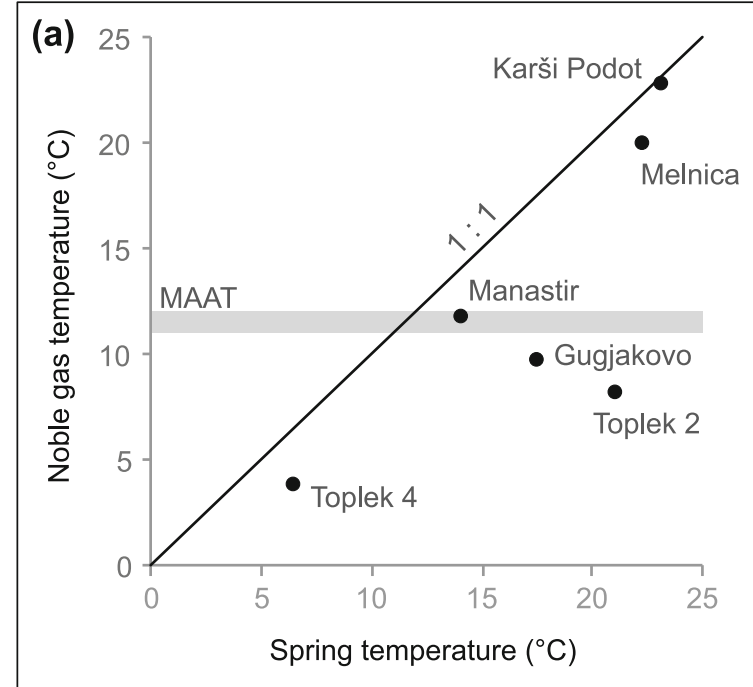

Fig. 11 Calculated noble gas recharge temperatures, plotted against: a measured spring water temperature; $\mathbf{b}$ groundwater $\delta^{18} \mathrm{O}$. MAAT is the mean annual temperature at the spring sites, and MAP is the weighted

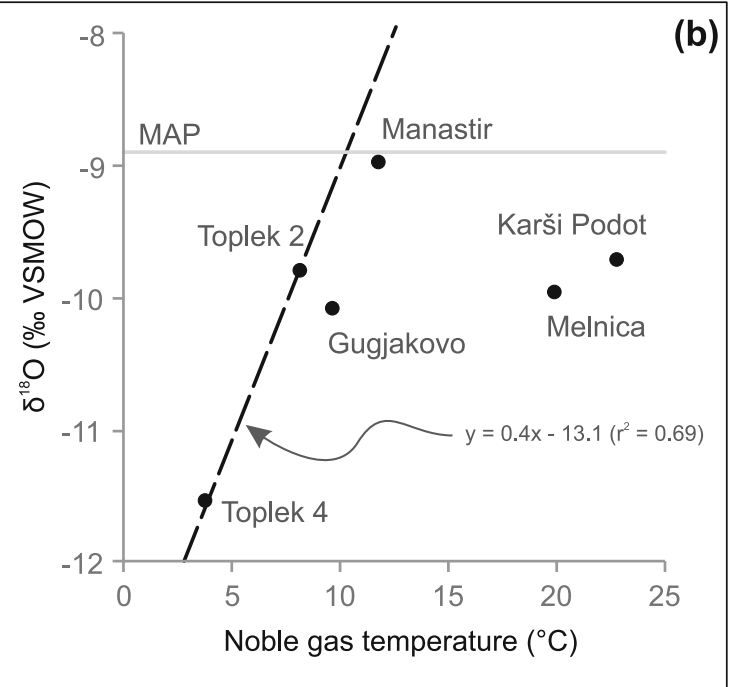

mean annual $\delta^{18} \mathrm{O}$ in local precipitation. Dashed line (b) shows the relationship of mean monthly air temperature to monthly $\delta^{18} \mathrm{O}$ in local precipitation (2018-2019) 
air and tritiogenic ${ }^{3} \mathrm{He}\left(R_{\mathrm{c}} / R_{\mathrm{a}}\right)$, and the ${ }^{4} \mathrm{He} /{ }^{20} \mathrm{Ne}$ ratio. For Melnica and Gugjakovo, considering the high nonatmospheric He concentration, the ${ }^{3} \mathrm{He}_{\text {trit }}$ contribution is small. Nevertheless, the ${ }^{3} \mathrm{He}$ concentration was corrected based on a ${ }^{3} \mathrm{He}_{\text {trit }}$ value calculated using the maximum possible ${ }^{3} \mathrm{H}$ input value that can decay to the measured one in the period since the beginning of the thermonuclear testing (taken as 1953). Using ${ }^{4} \mathrm{He} /{ }^{20} \mathrm{Ne}$ ratio of 1000 and $R / R_{\mathrm{a}}$ of 8 and 0.02 for the mantle and crustal end-member (Ozima and Podosek 2002), respectively, the calculated mantle He contribution at Melnica is $10 \%$ and at Gugjakovo 9\%, with also small (2\%) mantle contribution found at Karši Podot. Manastir and Toplek 2 have a mixture of crustal and atmospheric helium, while Toplek 4 has only atmospheric helium (Fig. 12).

The ${ }^{3} \mathrm{H}$ values of studied springs are lower than the decayed yearly ${ }^{3} \mathrm{H}$ values for Vienna precipitation (Fig. 13). As pointed out, this likely reflects the proportion of the young water fraction, although the actual magnitude could differ due to slightly different values for the local precipitation ${ }^{3} \mathrm{H}$ compared to the used dataset. The mixing of young and old water and their variable fractions are also indicated by other parameters such as the combined presence of ${ }^{3} \mathrm{H}$ with very low values for ${ }^{14} \mathrm{C}$, and water temperature. However, it should be noted here that the ${ }^{3} \mathrm{H}-{ }^{3} \mathrm{He}$ age at Karši Podot might be an overestimation due to contribution of mantle ${ }^{3} \mathrm{He}$; this is because $2 \%$ mantle helium was estimated based on the combined helium and neon isotope data.

By using the ${ }^{3} \mathrm{H}^{3} \mathrm{He}$ apparent ages to constrain the recharge period of the young component, for Karši Podot, from the yearly precipitation ${ }^{3} \mathrm{H}$ dataset, $30-47 \%$ of young groundwater is found (22.4-128\% if the monthly ${ }^{3} \mathrm{H}$ dataset is used), with the maximum value clearly an overestimation (Table 8). For Manastir, the estimated young groundwater contribution is $32-54 \%$ based on the yearly data, or $25-80 \%$ based on the monthly data. However, this might be an underestimation.
Although there are no local data available for the estimated recharge period, recent monitoring (since 2018) of ${ }^{3} \mathrm{H}$ in the local precipitation shows ${ }^{3} \mathrm{H}$ values as low as $4-5 \mathrm{TU}$ for the winter period. If similar values are assumed for the estimated recharge period (2005-2012), then the ${ }^{3} \mathrm{H}$ value at Manastir can be explained by ${ }^{3} \mathrm{H}$ decay from precipitation infiltrated dominantly during the winter period, thus the water represents only young groundwater. Toplek 2 is much lower than the precipitation curve, based on which the estimated young groundwater contribution is $13-19 \%$ (yearly data) or 10 $35 \%$ (monthly data).

\section{Radiocarbon and the mean residence time of the old groundwater}

The measured DIC ${ }^{14} \mathrm{C}$ concentrations $\left({ }^{14} \mathrm{C}_{\mathrm{DIC}}\right)$ range from 9.7 to $71.4 \mathrm{pMC}$, and also show three groups of values: Melnica (9.7 pMC) and Karši Podot (15.3 pMC) have the lowest, Toplek 2 (48.5 pMC) and Gugjakovo (48.9 pMC) intermediate, and Toplek 4 (68.4) and Manastir (71.4) the highest concentrations (Table 9; Fig. 14a). Based on their ${ }^{3} \mathrm{H}-{ }^{3} \mathrm{He}$ age and carbon isotope composition, Manastir and Toplek 4 are considered as modern waters, with their ${ }^{14} \mathrm{C}$ values diluted by carbonate dissolution under a system mostly closed to soil $\mathrm{CO}_{2}$. The waters at Melnica, Karši Podot and Gugjakovo represent a mixture of young and old groundwater, and from their geochemical composition it is evident that Gugjakovo has the highest and Melnica the lowest contribution of young groundwater.

As discussed before, Karši Podot and Gugjakovo likely represent mixtures with variable contributions of the same end-members for the young and old groundwater. Furthermore, from the ${ }^{3} \mathrm{H}-{ }^{3} \mathrm{He}$ age, the recharge period for the young component (1986-1989) is known, for which the ${ }^{14} \mathrm{C}$ of the atmospheric $\mathrm{CO}_{2}$ (Hua et al. 2013) was between

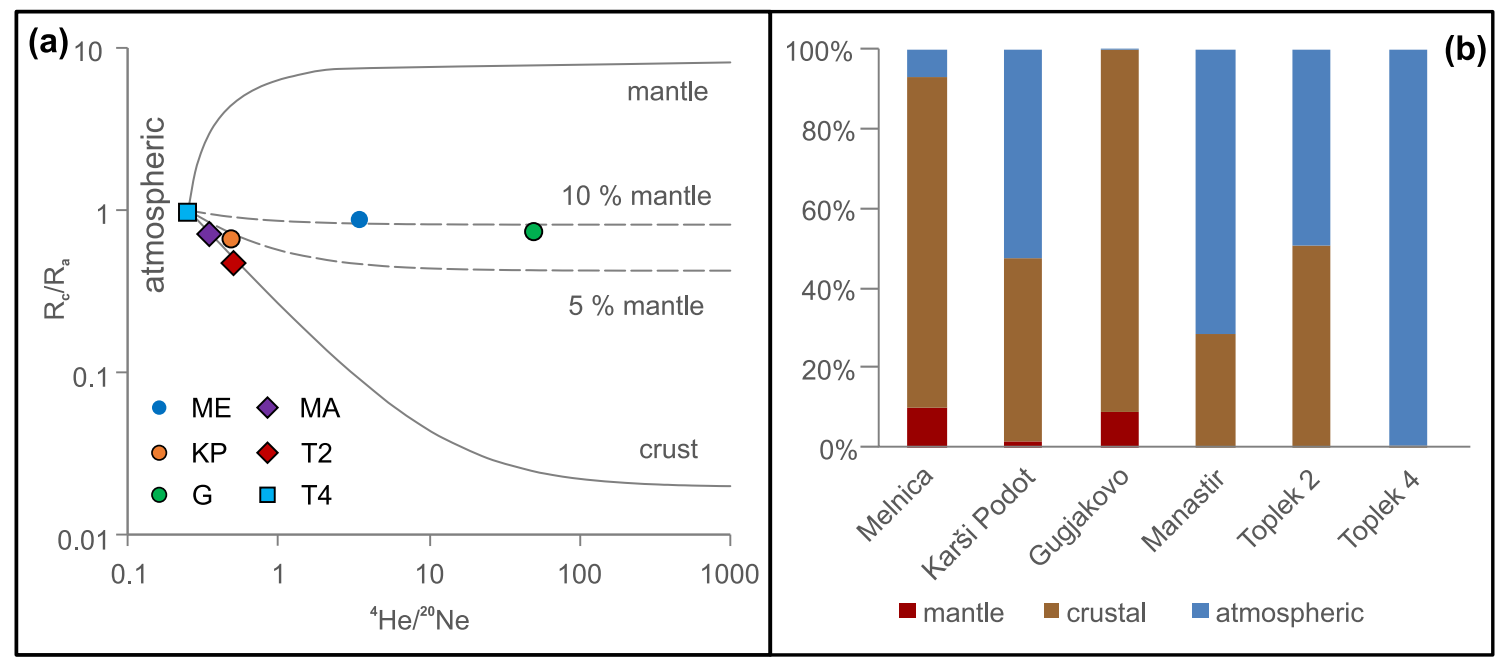

Fig. 12 Helium components in the studied groundwater, corrected for excess air and tritiogenic ${ }^{3} \mathrm{He}$ : a three-component (atmospheric, mantle, crustal) helium mixing plot; b calculated percentages of mantle-, crustal- and air-derived helium. Sample codes (a) same as in Fig. 7 
Fig. 13 Comparing measured spring ${ }^{3} \mathrm{H}$ values with their ${ }^{3} \mathrm{H}-{ }^{3} \mathrm{He}$ apparent ages $(1 \sigma$ uncertainty) to historical ${ }^{3} \mathrm{H}$ in precipitation (Vienna GNIP station) decayed to the sampling year of 2018. Sample codes same as in Fig. 7

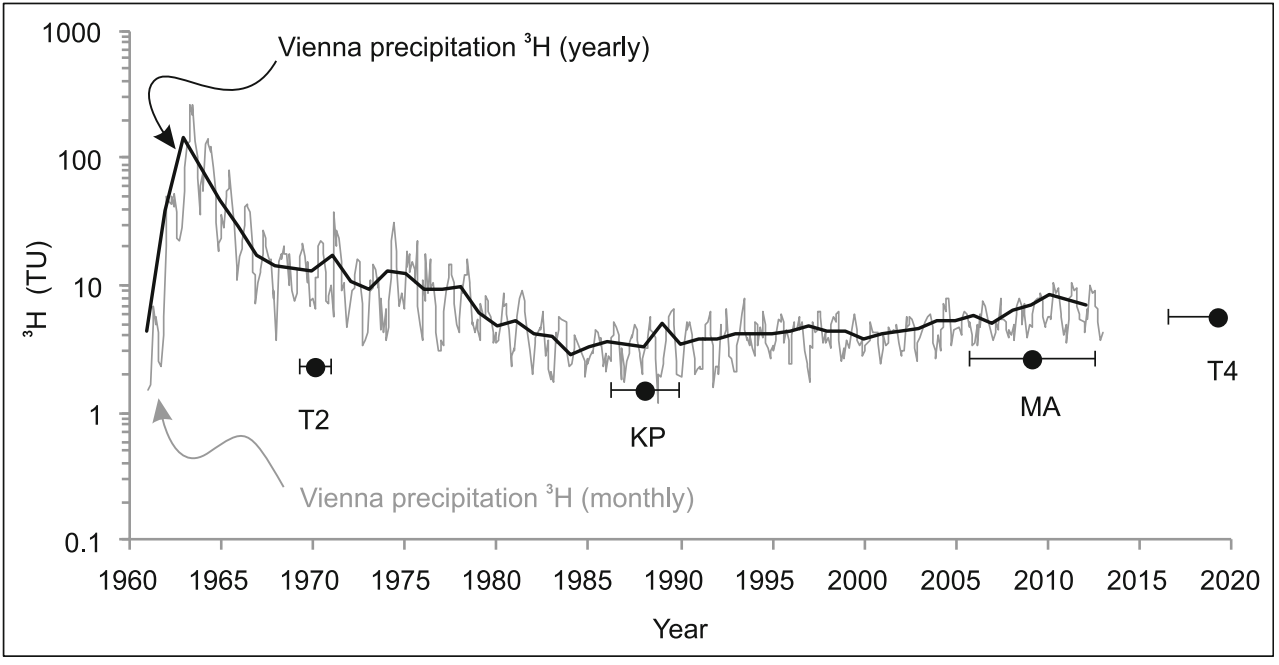

116 and $119 \mathrm{pMC}$ (mean $117.5 \mathrm{pMC}$ ). Using the approach detailed in section 'Estimating the carbon isotope composition of the groundwater end-member", the calculated carbon isotope composition of the young component is $58.8 \mathrm{pMC}{ }^{14} \mathrm{C}$ and $-8.9 \% \circ \delta^{13} \mathrm{C}$ (Fig. 14b). The old groundwater at Karši Podot and Gugjakovo (Podot locality), calculated from the carbon isotope composition of the young groundwater and Karši Podot and the estimated young fraction at Karši Podot, thus has ${ }^{14} \mathrm{C}$ of $2.7 \mathrm{pMC}$ and $\delta^{13} \mathrm{C}$ of $0.07 \%$, reflecting the large contribution of endogenic $\mathrm{CO}_{2}$. From the binary mixing model and the estimated compositions of the end-members, $82 \%$ contribution of the young groundwater can be found at Gugjakovo.

To calculate a radiocarbon age for the old component at Podot (Gugjakovo and Karši Podot), first a correction has to be made for the dilution of the soil ${ }^{14} \mathrm{C}$ signature by addition of ${ }^{14} \mathrm{C}$-free (dead) carbon from dissolution of carbonate rock and endogenic $\mathrm{CO}_{2}$. Using the deconvoluted components of carbon in the old groundwater (section 'Stable isotope composition of DIC and the source of $\mathrm{CO}_{2}$ '; Table 6), and the approach detailed in section 'Correction for ${ }^{14} \mathrm{C}$-free dilution of DIC and calculating the age of the old groundwater', a dilution factor of 0.17 can be calculated, from which a conventional ${ }^{14} \mathrm{C}$ age of $15.3 \mathrm{ka}$ is obtained for the old groundwater at Karši Podot and Gugjakovo (Table 9).

For Melnica there is no separate estimate for the young fraction, so the same approach cannot be used to calculate the carbon isotope composition of the old component. However, the Melnica sample is very close to the $\delta^{13} \mathrm{C}-{ }^{14} \mathrm{C}$ mixing line of Podot locality (Fig. 14b), indicating that the old component at Melnica will not be significantly different. If no young groundwater contribution is assumed, the dilution factor $\mathrm{q}$ will be represented by the total of soil derived carbon (0.20), and from the measured ${ }^{14} \mathrm{C}$ of 9.7 pMC a ${ }^{14} \mathrm{C}$ age of $6.1 \mathrm{ka}$ can be calculated. This should be considered as a minimum age, as young groundwater contribution is clearly indicated by the presence of ${ }^{3} \mathrm{H}$. The ${ }^{14} \mathrm{C}$ age of $15.3 \mathrm{ka}$ obtained for Podot locality thus should be considered as a maximum age for Melnica. Using the carbon composition of the young end-member at Podot locality, a maximum contribution of $12.8 \%$ young groundwater can be calculated for Melnica, as well as an old end-member composition of $2.5 \mathrm{pMC}{ }^{14} \mathrm{C}$ and $0.24 \%$ o ${ }^{13} \mathrm{C}$ (Table 9).

Table 8 Tritium concentrations, ${ }^{3} \mathrm{H}-{ }^{3} \mathrm{He}$ apparent ages and ${ }^{3} \mathrm{H}$-based estimation of the young groundwater fraction

\begin{tabular}{|c|c|c|c|c|c|c|c|c|c|c|}
\hline \multirow[t]{2}{*}{ Spring } & \multirow{2}{*}{$\begin{array}{l}\text { Sampling } \\
\text { date }\end{array}$} & \multicolumn{2}{|l|}{${ }^{3} \mathrm{H}$} & \multicolumn{2}{|l|}{${ }^{3} \mathrm{He}_{\text {trit }}$} & \multicolumn{2}{|l|}{${ }^{3} \mathrm{H}-{ }^{3} \mathrm{He}$ age } & \multirow{2}{*}{$\begin{array}{l}\text { Recharge } \\
\text { period }\end{array}$} & \multirow{2}{*}{$\begin{array}{l}\text { Young - yearly } \\
\text { dataset }(\%)\end{array}$} & \multirow{2}{*}{$\begin{array}{l}\text { Young - monthly } \\
\text { dataset (\%) }\end{array}$} \\
\hline & & $\begin{array}{l}{ }^{3} \mathrm{H} \text { value } \\
(\mathrm{TU})\end{array}$ & $\pm(\mathrm{TU})$ & $\begin{array}{l}{ }^{3} \mathrm{He}_{\text {trit }} \text { value } \\
\left(\times 10^{-14} \mathrm{~cm}^{3}\right. \\
\mathrm{STP} / \mathrm{g})\end{array}$ & $\begin{array}{l} \pm \\
(\mathrm{TU})\end{array}$ & $\begin{array}{l}{ }^{3} \mathrm{H}-{ }^{3} \mathrm{He} \text { age } \\
\text { (value, years) }\end{array}$ & $\pm($ years $)$ & & & \\
\hline Gugjakovo Springs & 13.9.2018 & 3.35 & 0.06 & 909.0 & 23.5 & - & - & - & - & - \\
\hline Karši Podot & 14.9.2018 & 1.51 & 0.03 & 1.7 & 0.2 & 31 & 2 & 1986-1989 & $30-47$ & $22.4-128$ \\
\hline Melnica & 12.9.2018 & 1.74 & 0.04 & 67.8 & 1.9 & - & - & - & - & - \\
\hline Manastir & 12.9.2018 & 2.68 & 0.05 & 0.5 & 0.2 & 10 & 3 & 2005-2012 & $32-54$ & $25-80$ \\
\hline Toplek 2 & 11.9.2018 & 2.33 & 0.05 & 8.3 & 0.4 & 49 & 1 & 1969-1971 & $13-19$ & $10-35$ \\
\hline Toplek 4 & 15.3.2019 & 5.79 & 0.09 & 0.0 & 0.2 & 0 & 3 & 2016-2019 & 100 & 100 \\
\hline
\end{tabular}


Table 9 Radiocarbon ages and estimation of the old groundwater based on carbon isotopes

\begin{tabular}{|c|c|c|c|c|c|c|c|c|c|c|}
\hline Spring & $\begin{array}{l}\text { Date } \\
\text { (m.yyyy) }\end{array}$ & $\begin{array}{l}\delta^{13} \mathrm{C}_{\mathrm{DIC}} \\
(\% \circ)\end{array}$ & ${ }^{14} \mathrm{C}_{\text {DIC }}(\mathrm{pMC})$ & $\begin{array}{l}\text { Young } \\
\text { water } \\
(\%)\end{array}$ & $\delta^{13} \mathrm{C}_{\text {young }}(\% o)$ & ${ }^{14} \mathrm{C}_{\text {young }}(\mathrm{pMC})$ & $\delta^{13} \mathrm{C}_{\text {old }}(\% o)$ & ${ }^{14} \mathrm{C}_{\mathrm{old}}(\mathrm{pMC})$ & $q$ & $\begin{array}{l}{ }^{14} \mathrm{C} \text { age } \\
(\mathrm{ka})\end{array}$ \\
\hline $\begin{array}{c}\text { Gugjakovo } \\
\text { Springs }\end{array}$ & 9.2018 & -7.3 & $48.9 \pm 0.2$ & 82.4 & $-8.9 \pm 0.1$ & $58.8 \pm 0.8$ & $\begin{array}{c}+0.07 \pm \\
0.03\end{array}$ & $2.7 \pm 0.3$ & 0.17 & $15.3 \pm 1.0$ \\
\hline $\begin{array}{l}\text { Karši } \\
\text { Podot }\end{array}$ & 9.2018 & -1.9 & $15.3 \pm 0.1$ & - & & & & & & \\
\hline Melnica & 9.2018 & -0.9 & $9.7 \pm 0.1$ & $<12.8$ & - & - & $<+0.24$ & $>2.5$ & $<0.20$ & 6.1 to 15.3 \\
\hline Toplek 2 & 9.2018 & -7.9 & $48.5 \pm 0.2$ & - & -9.3 & $76.8 \pm 1.3$ & $-7.4 \pm 0.3$ & $38.7 \pm 6.8$ & 0.46 & $1.5 \pm 1.5$ \\
\hline Manastir & 9.2018 & -9.6 & $71.4 \pm 0.2$ & Modern & & & & & & \\
\hline Toplek 4 & 3.2019 & -9.3 & $68.4 \pm 0.3$ & Modern & & & & & & \\
\hline
\end{tabular}

Based on the ${ }^{3} \mathrm{H}$ data Toplek 2 also appears to be a mixture of old groundwater with $10-35 \%$ young groundwater. The $\delta^{13} \mathrm{C}$ of $-9.3 \%$ at Toplek 4 can be considered as a representative value for the young component evolved under closed system carbonate dissolution. From this value and the fractions for the young component, a $\delta^{13} \mathrm{C}$ value of $-7.4 \pm 0.3 \%$ o can be calculated for the old groundwater. The ${ }^{14} \mathrm{C}$ composition of the young component at Toplek 2, should be higher than the one of Toplek 4 as, based on the ${ }^{3} \mathrm{H}^{3} \mathrm{He}$ age, it must have been affected by bomb-derived ${ }^{14} \mathrm{C}$. For the estimated recharge period (1969-1971) the atmospheric ${ }^{14} \mathrm{C}$ was $151-$ 156 pMC (mean 153.5 pMC), and with half of that (closed system dissolution) as the young component ${ }^{14} \mathrm{C}$ composition, the old groundwater ${ }^{14} \mathrm{C}$ at Toplek 2 should have $38.7 \pm 6.8$ $\mathrm{pMC}$. The dilution factor $\mathrm{q}$ at Toplek, calculated from the carbon components is 0.46 , using which a ${ }^{14} \mathrm{C}$ age of $1.5 \pm$ $1.5 \mathrm{ka}$ can be calculated (Table 9). The large age error at Toplek 2 is due to the large error in the estimate for the contribution of the young groundwater.

\section{Geothermometry}

An attempt was made to estimate the reservoir temperatures of the warmest springs using different geothermometers based on:
$\mathrm{SiO}_{2}$ (Fournier 1977), Na-K-Ca (Fournier and Truesdell 1973) with corrections for $\mathrm{Mg}$ (Fournier and Potter 1979) and $\mathrm{CO}_{2}$ (Paceš 1975), as well as K-Mg (Giggenbach 1988) and $\delta^{18} \mathrm{O}_{\mathrm{SO} 4-\mathrm{H} 2 \mathrm{O}}$ (McKenzie and Truesdell 1977). The estimated reservoir temperatures range from 60 to $175{ }^{\circ} \mathrm{C}$ (Table 10). The most comparable temperature estimates are given by the $\mathrm{SiO}_{2}, \mathrm{~K}-\mathrm{Mg}$ and $\mathrm{Na}-\mathrm{K}-\mathrm{Ca}$ ( $\mathrm{pCO}_{2}$ corrected) geothermometers, with values of $60-65^{\circ} \mathrm{C}$ for Karši Podot, $60-71^{\circ} \mathrm{C}$ for Melnica and $64-88^{\circ} \mathrm{C}$ for Toplek 2 . These estimates are considered here as minimum temperatures, as the waters were diluted by mixing with $10-20 \%$ cold water, although the cold water has likely much lower dissolved content.

Palinkaš et al. (2018) estimated temperatures from $\sim 100^{\circ} \mathrm{C}$ to more than $200{ }^{\circ} \mathrm{C}$ for the hydrothermal fluids that carried the mineralization of $\mathrm{Au}, \mathrm{As}, \mathrm{Sb}$ and $\mathrm{Tl}$ at Allchar. Considering this, $100{ }^{\circ} \mathrm{C}$ can be considered as an upper limit for the reservoir temperature of these groundwater systems. The lower estimated reservoir temperatures than the earlier hydrothermal systems likely reflect the later stage of the thermal evolution of these systems. This is also supported by the estimated temperature of $<50{ }^{\circ} \mathrm{C}$ for the older phase $(>1.5 \mathrm{Ma})$ of calcite deposition in Provalata Cave (located above Melnica Spring), that acted as a feeder to a former spring (Temovski et al. 2013; Temovski 2016).

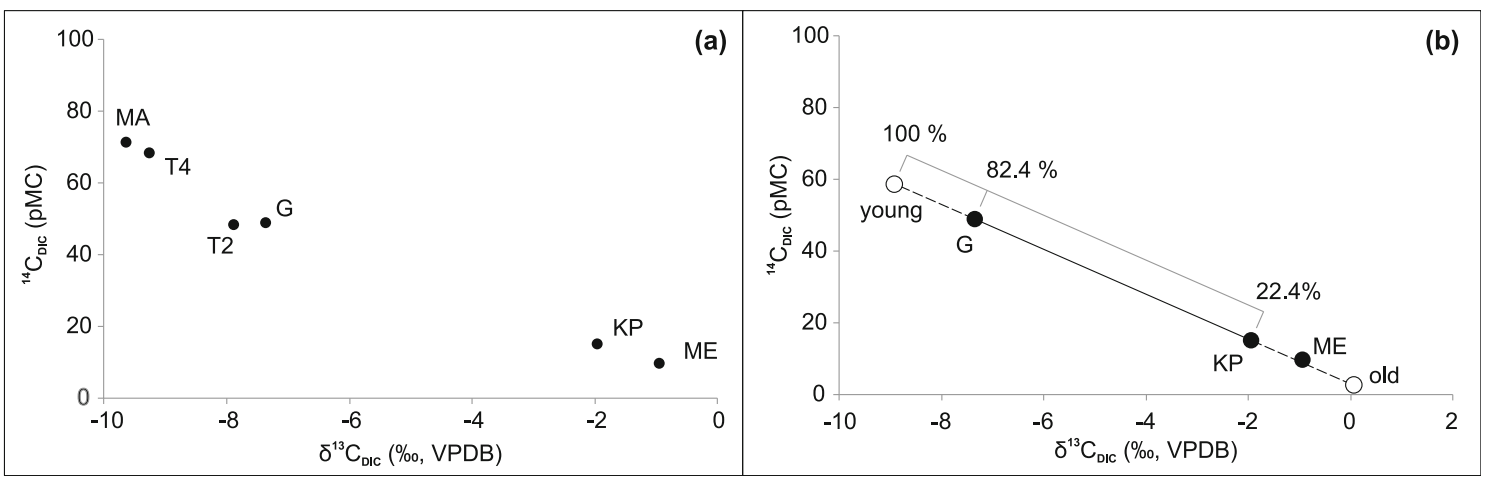

Fig. 14 Relationship of $\delta{ }^{13} \mathrm{C}$ and ${ }^{14} \mathrm{C}$ in DIC: $\mathbf{a}$ all samples; $\mathbf{b}$ derivation of the young and old groundwater carbon isotope composition at Podot locality. Sample codes same as in Fig. 7 
Table 10 Estimated reservoir temperatures $\left({ }^{\circ} \mathrm{C}\right)$ with different geothermometers. For the Na-Ka-Ca geothermometer, the calculation was done using a value of $1 / 3$ for $\beta$ (Fournier and Truesdell 1973)

\begin{tabular}{|c|c|c|c|c|c|c|c|}
\hline Spring & $\mathrm{T}_{\text {spring }}$ & $\delta^{18} \mathrm{O}_{\mathrm{SO} 4-\mathrm{H} 2 \mathrm{O}}$ & $\mathrm{Na}-\mathrm{K}-\mathrm{Ca}$ & $\mathrm{Na}-\mathrm{K}-\mathrm{Ca}-\mathrm{Mg}_{\text {corr }}$ & $\mathrm{Na}-\mathrm{K}-\mathrm{Ca}-\mathrm{CO}_{2 \text { corr }}$ & $\mathrm{K}-\mathrm{Mg}$ & $\mathrm{SiO}_{2}$ \\
\hline Karši Podot & 23 & 106 & 175 & 175 & 63 & 60 & 65 \\
\hline Melnica & 22 & 109 & 173 & 173 & 63 & 60 & 71 \\
\hline Toplek 2 & 21 & 174 & 175 & 175 & 88 & 73 & 64 \\
\hline
\end{tabular}

Geothermal gradients are not well constrained, with reported values of more than $40{ }^{\circ} \mathrm{C} / \mathrm{km}$ for the Vardar Zone (Kotevski 1987). Using a geothermal gradient estimate of $40{ }^{\circ} \mathrm{C} / \mathrm{km}$, the circulation depths are ranging from $0.9-1 \mathrm{~km}$ at Karši Podot, $0.9-1.2 \mathrm{~km}$ at Melnica and 1.1-1.7 km at Toplek 2. However, the geothermal gradient in this area is also likely underestimated (especially at Toplek locality), thus both the reservoir temperature and the circulation depth are considered as a loose approximation.

\section{Discussion}

\section{Estimation of groundwater component fractions by combined use of ${ }^{14} \mathrm{C}, \delta^{13} \mathrm{C},{ }^{3} \mathrm{H}$ and noble gases}

As indicated by several parameters in their geochemical composition (e.g. temperature (T), EC, TDS, ${ }^{3} \mathrm{H},{ }^{14} \mathrm{C}, \delta^{13} \mathrm{C}$ ), the studied spring waters at Melnica, Karši Podot and Gugjakovo represent mixtures of two end-members, a young fresh groundwater and an old thermal groundwater. Without clear end-member representatives at the studied locations, the approach to estimate their compositions is based on one main assumption: the selected springs (Karši Podot and Gugjakovo) share the same end-members, i.e. they are mixtures of different proportions from the same groundwater end-members. As indicated by their close proximity and especially their geochemical composition, this assumption seems valid for the two selected springs, with Karši Podot having higher contribution of the old groundwater (e.g. higher T, EC, TDS, $\delta^{13} \mathrm{C}$ and trace element concentrations, and lower ${ }^{3} \mathrm{H}$ and ${ }^{14} \mathrm{C}$ ) and Gugjakovo having higher contribution of the young groundwater (e.g. lower T, EC, TDS, $\delta^{13} \mathrm{C}$ and trace element concentrations, and higher ${ }^{3} \mathrm{H}$ and ${ }^{14} \mathrm{C}$ ). The fraction of the young component was estimated based on combined use of the spring water ${ }^{3} \mathrm{H}$ concentration and ${ }^{3} \mathrm{H}-{ }^{3} \mathrm{He}$ apparent age (young component recharge period), by comparison to the historical record of ${ }^{3} \mathrm{H}$ concentration in precipitation decayed to the sampling date. Assuming carbonate rock dissolution under a system closed to soil $\mathrm{CO}_{2}$, the carbon isotopic composition of the young component was estimated from atmospheric $\mathrm{CO}_{2}\left({ }^{14} \mathrm{C}\right)$ and the linear relationship of the measured carbon isotope composition at Gugjakovo and Karši Podot $\left(\delta^{13} \mathrm{C}\right)$. To test the reliability of this estimate, the $\delta^{13} \mathrm{C}$ of the soil equilibrated $\mathrm{CO}_{2}$ from $\delta^{13} \mathrm{C}_{\text {young }}=0.5 \times\left(\delta^{13} \mathrm{C}_{\mathrm{CO} 2}+\right.$ $\delta^{13} \mathrm{C}_{\text {rock }}$ ), assuming closed system carbonate dissolution (Han and Plummer 2016). Using the $\delta^{13} \mathrm{C}$ value of the young component $\left(-8.9 \%\right.$ ) and a value of $2.8 \%$ for $\delta^{13} \mathrm{C}_{\text {rock }}$ (section 'Sources of $\mathrm{CO}_{2}$ and deconvolution of carbon components in DIC'), the calculated $\delta^{13} \mathrm{C}$ of the soil equilibrated $\mathrm{CO}_{2}$ of the young groundwater is $-20.7 \%$. This is close to the values obtained for the soil-derived external $\mathrm{CO}_{2}$ at Manastir and Toplek 4, where closed system carbonate dissolution was found (section 'Stable isotope composition of DIC and the source of $\mathrm{CO}_{2}$ ').

\section{The source of the groundwater}

Water stable isotopes, as well as NGTs, clearly show that the groundwater is of meteoric origin. The $\delta^{18} \mathrm{O}$ and NGT values reflect recharge under cooler temperatures than local MAAT, which, especially for the young shallow groundwater, probably reflects higher infiltration of water during the winter period. This is to be expected in temperate areas, where even though the precipitation amount might be lower in the winter period, higher evapotranspiration in the summer period prevents larger infiltration (e.g. Jasechko et al. 2014). However, at Karši Podot and Melnica, where the contribution of shallow young groundwater is small, even though the NGTs are not reflecting recharge values, lower $\delta^{18} \mathrm{O}$ and $\delta^{2} \mathrm{H}$ values might reflect lower MAAT values, which could be as a result of recharge of the old groundwater at cooler climate conditions, or considering the hydrogeological settings, recharge at higher elevations, or both.

\section{Water-rock interactions}

Although the trace element composition indicates interaction with volcanic rocks of Kožuf-Kozjak volcanic system, as well as metamorphic and magmatic rocks of the Pelagonian basement, the major ion composition clearly reflects the carbonate aquifer lithology. $\mathrm{Mg} / \mathrm{Ca}$ molar ratios indicate dissolution of both calcite and dolomite minerals at Melnica, Karši Podot and Gugjakovo springs. The $\mathrm{Mg} / \mathrm{Ca}$ ratio at Melnica, discharging from calcite marble, indicates also flow through the dolomite marble formation, which is quite plausible 
considering the thermally altered parts found in the nearby dolomite marble formation north from Melnica (Fig. 2; Temovski 2016). At Karši Podot the $\mathrm{Mg} / \mathrm{Ca}$ ratio is similar, although the water is discharging from dolomite marble. This could be due to incongruent dissolution within the dolomite formation, as such a process has been identified in Karši Podot Cave. Within the dolomite marble, the porosity was formed by ghost-rock weathering (e.g. Dubois et al. 2014), i.e. preferential dissolution of calcite due to cooling of thermal waters, leaving in-situ dolomitic sand residue (Temovski 2016, 2017). As the slowly moving thermal waters were lacking in sufficient energy to carry away the remaining dolomite sand, the penetrable-size cave passages were formed only when the high-energy back-flooding water of Crna Reka removed the dolomite sand residue. The higher $\mathrm{Mg} / \mathrm{Ca}$ ratio at Gugjakovo indicates that the source of the fresh water component is the dolomite marble formation to the north, instead of the previously considered Upper Cretaceous limestone formation (Temovski 2016).

\section{The groundwater flow systems}

Compared to what is commonly reported for thermal karst groundwater at the discharge areas (Goldscheider et al. 2010), the studied springs generally have lower total dissolved content $(<1,000 \mathrm{mg} / \mathrm{L})$ and low values for dissolved $\mathrm{SO}_{4}{ }^{2-}$ and $\mathrm{Cl}^{-}$. Lukewarm spring waters $\left(<30^{\circ} \mathrm{C}\right)$ of lower salinity discharging at the Buda Thermal Karst (Mádl-Szönyi and Tóth 2015) have been interpreted as part of an intermediate groundwater flow in unconfined settings, that has somewhat increased $\mathrm{Cl}^{-}$concentration due to mixing along the discharge zone with basinal fluids of a confined, deeper, regional groundwater flow system. Groundwater of lower salinity related to hypogene karst systems is also found in regions where young volcanism is present, generally associated with hydrothermal activity, with higher concentrations of $\mathrm{CO}_{2}$ and/or $\mathrm{H}_{2} \mathrm{~S}$ (Klimchouk 2017). For the Mariovo hypogene karst systems, based on the geochemical composition of the studied springs, mixing of waters from two groundwater flow systems is identified: a young cold freshwater and an older, chemically more evolved thermal water.

The mean residence time of the young shallow groundwater is constrained by the ${ }^{3} \mathrm{H}_{-}{ }^{3} \mathrm{He}$ apparent ages, and ranges from recent ( $<3$ years) at Toplek $4, \sim 10$ years at Manastir, $\sim 30$ years at Podot locality and $\sim 50$ years at Toplek 2 . Manastir and Toplek 4 have the youngest groundwater, which reflects the relatively fast groundwater flow of the local groundwater systems developed in highly permeable travertine and dolomite of higher permeability, respectively. The young groundwater at Podot and Toplek is somewhat older, and reflects either slower groundwater flow of local groundwater systems in less permeable marble and dolomite rocks, or possibly (e.g. in the north stretching marble stipe at Podot) an intermediate groundwater flow system.

The ${ }^{14} \mathrm{C}$ age of the old groundwater component at Podot, if based on the calculated carbon isotope composition $(\sim 30 \mathrm{ka})$, is clearly overestimated. This is due to addition of ${ }^{14} \mathrm{C}$-free carbon, partly due to dissolution of carbonate rock, but more importantly due to the large contribution (up to $54 \%$ of total DIC) of endogenic $\mathrm{CO}_{2}$ (Table 6). Nevertheless, the deadcarbon dilution-corrected ${ }^{14} \mathrm{C}$ age at Podot $(\sim 15 \mathrm{ka})$ still reflects long mean residence time of the old groundwater, with the estimated mean residence time at Melnica between $\sim 6$ and $\sim 15 \mathrm{ka}$. The circulation depth of $0.9-1.2 \mathrm{~km}$ at Melnica and Podot indicates deeper circulation of the old groundwater, which can be achieved if the flow is along the dip of the carbonate formation. Considering the topographic position of the discharge areas, the local geological constrains, the estimated circulation depth, the inferred water-rock interactions and the higher recharge elevations, the old groundwater component at Podot represents the discharge of a regional groundwater flow system. The groundwater at Melnica has somewhat lower residence time and represents either a shorter flow path (a subsystem) of the same deeper regional groundwater flow system after reaching a deep fault, or a shallower intermediate groundwater flow system. However, the latter is probably less likely, considering the very similar geochemical properties with the old groundwater at Podot. The very high uncertainty in the ${ }^{14} \mathrm{C}$ age of the old groundwater at Toplek does not allow for any meaningful interpretation.

\section{The hypogene speleogenetic settings}

Most of the carbonate rock dissolution likely occurs along the rising limb of the flow in the discharge zone. While increased dissolution here due to mixing with shallower groundwater (i.e. mixing corrosion) is possible, the high dissolved $\mathrm{CO}_{2}$ concentrations are probably of higher importance (Dublyansky 2000). Additionally, cooling due to rising of the thermal groundwater and/or mixing with the cold shallow water, can further increase dissolution due to the retrograde calcite solubility (Andre and Rajaram 2005). These processes are consistent with the findings from Provalata Cave, where the older speleogenetic phase is associated with dissolution of the marble bedrock due to cooling of $\mathrm{CO}_{2}$-rich thermal waters (Temovski et al. 2013). Calcite deposited in isotopic equilibrium with the groundwater DIC at Melnica Spring will have a $\delta^{13} \mathrm{C}$ of ca. $+4 \%$, which is comparable with the measured high $\delta^{13} \mathrm{C}$ values (ca. $+7 \%$ ) in the calcite deposits of Provalata Cave (Temovski et al. 2013). This suggests that this system has operated for a long time, and the abundant travertine deposits in the surroundings (Temovski 2016), deposited in different environments (e.g. lacustrine limestone, paludal limestone, spring tufa), are also likely related to increased alkalinity supplied by these deep groundwater systems. 
Mantle helium contribution in the dissolved gases at Podot and Melnica of up to $10 \%$ is consistent with the findings on the southern foothill side of Kožuf-Kozjak volcanic system in Greece, where up to $16 \%$ mantle helium was reported (Daskalopoulou et al. 2018). $\mathrm{H}_{2} \mathrm{~S}$ oxidation is a likely source of the dissolved sulfate at Melnica and Karši Podot. A magmatic origin of $\mathrm{H}_{2} \mathrm{~S}$ is also possible based on the sulfur isotopic composition, as well as the presence of mantle helium. Mariovo hypogene karst system shows some geochemical similarities to other hypogene karst systems related to young volcanism such as the presence of mantle derived gases, e.g. Sistema Zacatón in Mexico (Gary and Sharp 2006), Mt. Gambier in Australia (Webb et al. 2010) or Konya Basin in Turkey (Bayari et al. 2009b), except that the $\mathrm{CO}_{2}$ at Mariovo is of dominantly metamorphic origin. However, it shares none of the morphological expressions of the discharge zone, with large collapse dolines developed at Sistema Zacatón, Mt. Gambier and Konya Basin, and only relatively small caves found in Mariovo. One reason for this can be the structural difference, with Mariovo hypogene karst developed in highly dipping strata, while the others are developed in subhorizontal strata, but also the high difference in fluid flux, with Mariovo having both smaller flow rate and gas concentrations.

\section{Conceptual model of the Mariovo hypogene karst system}

The results from this geochemical study allow one to put some constraints on the Mariovo hypogene karst system and develop a conceptual model (Fig. 15). The water is of meteoric origin, likely infiltrated along fault structures in the southern parts of the marble stripe. It reached depth of around $1 \mathrm{~km}$, which could be achieved by circulating along fault structures and/or along the dip of the carbonate formation, and then following northward in strike direction. The output zones are at the intersection of low topography and major fault structures at Podot and Melnica localities. Podot locality, is the furthest $(\sim 25 \mathrm{~km})$ and lowest output, with water emerging $\sim 15 \mathrm{ka}$ after recharge. Discharge of endogenic gases, mostly metamorphic $\mathrm{CO}_{2}$ and especially some contribution of mantle helium in the output zone indicates deep setting of these fault structures, related to the extensional tectonics of the area. Melnica is likely a subsystem of the same groundwater system, with a shorter flow path $(\sim 18 \mathrm{~km})$ and younger age, formed because part of the groundwater was likely forced upward after reaching a deep fault with a higher gas flux.

Most of the carbonate rock dissolution is likely achieved along the rising limb, due to cooling with acidity acquired from endogenic $\mathrm{CO}_{2}$. At depth, closer to the recharge area, the groundwater has contact with rocks from the Kožuf-Kozjak Neogene-Quaternary volcanism. Contact with the underlying metamorphic basement and the granitoid bodies perching it, is also achieved along the northward flow either at depth or along the rising limb in the output zone. In the southern parts, between the recharge zone and Melnica, a schist formation is separating the lower, mostly dolomite marble formation, from the upper, calcite marble formation, partly confining the groundwater system, and forcing the northward deep flow. At the output zones, the deep circulating old water of the regional to intermediate hypogene groundwater system is mixing with the shallow recent water part of the local epigene groundwater systems. This hypogene groundwater system has been active for a long time, as evidenced by the $>1.5$ Ma age of deposits in Provalata Cave (Temovski et al. 2013). The large travertine deposits found within, or topping, the Pliocene-Quaternary basin sediments near Melnica or Podot are likely related to older stages of the same hypogene karst system.

\section{Conclusion}

This study presents an approach whereby various geochemical methods are applied in order to identify different components

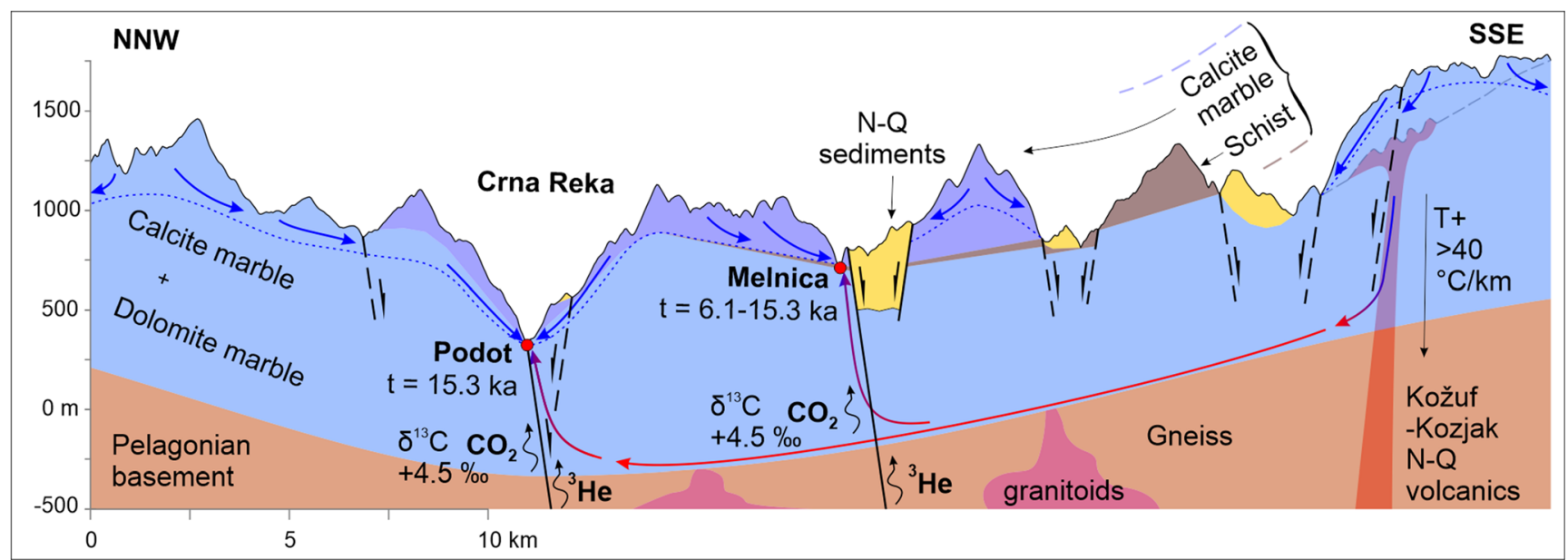

Fig. 15 Conceptual model of the Mariovo hypogene groundwater system. The NNW-SSE direction of the cross-section represents the strike of the carbonate formation. The thickness of the carbonate formation is the apparent thickness along the dip of the formation 
and properties of groundwater associated with hypogene karst systems. It demonstrates the use of radiogenic and stable isotopes, noble gases and major ion and trace element composition in a case where sampling was restricted only to the spring sites, and in a limited number of locations. In the absence of clearly defined end-member compositions, by combining multiple geochemical methods the groundwater components are identified, as well as their composition and mean residence time, and their geochemical evolution. Furthermore, the carbon sources contributing to the DIC are identified, based on which the carbon isotope composition of the endogenic $\mathrm{CO}_{2}$ is modeled. This is then used to correct the radiocarbon composition for the dilution of the soil ${ }^{14} \mathrm{C}$ signature by addition of ${ }^{14} \mathrm{C}$-free carbon from dissolution of carbonate rock and endogenic $\mathrm{CO}_{2}$, and calculate a radiocarbon age for the old component.

The obtained results show that the main studied springs represent an output part of a regional hypogene karst groundwater system with a deep-circulating $(\sim 1 \mathrm{~km})$, old $(\sim 15 \mathrm{ka})$, thermal $\left(\geq 60{ }^{\circ} \mathrm{C}\right)$ water, where the old groundwater mixes with young $\left(<50\right.$ years), cold $\left(<14^{\circ} \mathrm{C}\right)$ and shallow epigene karst groundwater. These output zones of the hypogene karst system are located at the interception of low topography and deep fault structures along which there is circulation of deepseated gases, dominantly $\mathrm{CO}_{2}$ of metamorphic origin $(+4.5 \%$ o $\delta^{13} \mathrm{C}$ ), with a contribution of mantle helium. The chemical composition of the water indicates interaction at depth with volcanic rocks from the N-Q Kožuf-Kozjak volcanism, as well as with metamorphic rocks and granitoids of the Pelagonian basement. The groundwater geochemistry results of this study complement previous findings based on geochemistry of fossil cave deposits, and confirm that dissolution of carbonate rocks due to cooling of $\mathrm{CO}_{2}$-rich thermal waters is the main hypogene geochemical process in the area.

Supplementary Information The online version contains supplementary material available at https://doi.org/10.1007/s10040-020-02293-w.

Acknowledgements We would like to thank the members of SK Zlatovrv - Prilep for assistance during sampling. We are also thankful to the editor and the two anonymous reviewers for their useful comments and suggestions which improved the manuscript.

Funding Open Access funding provided by ELKH Institute for Nuclear Research. This research was supported by the European Union and the State of Hungary, co-financed by the European Regional Development Fund in the project of GINOP-2.3.2-15-2016-00009 'ICER'

Open Access This article is licensed under a Creative Commons Attribution 4.0 International License, which permits use, sharing, adaptation, distribution and reproduction in any medium or format, as long as you give appropriate credit to the original author(s) and the source, provide a link to the Creative Commons licence, and indicate if changes were made. The images or other third party material in this article are included in the article's Creative Commons licence, unless indicated otherwise in a credit line to the material. If material is not included in the article's Creative Commons licence and your intended use is not permitted by statutory regulation or exceeds the permitted use, you will need to obtain permission directly from the copyright holder. To view a copy of this licence, visit http://creativecommons.org/licenses/by/4.0/.

\section{References}

Aeschbach-Hertig W, Solomon DK (2013) Noble gas thermometry in groundwater hydrology. In: Burnard P (ed) The Noble gases as geochemical tracers. Springer, Heidelberg, Germany, pp 81-122

Aeschbach-Hertig W, Peeters F, Beyerle U, Kipfer R (2000) Palaeotemperature reconstruction from noble gases in ground water taking into account equilibration with entrapped air. Nature 405: 1040-1044. https://doi.org/10.1038/35016542

Aeschbach-Hertig W, El-Gamal H, Wieser M, Palcsu L (2008) Modeling excess air and degassing in groundwater by equilibrium partitioning with a gas phase. Water Resour Res 44:449-461. https://doi.org/10. 1029/2007WR006454

Andre BJ, Rajaram H (2005) Dissolution of limestone fractures by cooling waters: early development of hypogene karst systems. Water Resour Res 41:W01015. https://doi.org/10.1029/ 2004WR003331

Audra P, Bigot J-Y, Mocochain L (2002) Hypogenic caves in Provence (France): specific features and sediments. Acta Carsol 31(3):33-50. https://doi.org/10.3986/ac.v31i3.378

Bayari CS, Ozyurt NN, Kilani S (2009a) Radiocarbon age distribution of groundwater in the Konya Closed Basin, central Anatolia, Turkey. Hydrogeol J 17:347-365. https://doi.org/10.1007/s10040-0080358-2

Bayari CS, Pekkan E, Ozyurt NN (2009b) Obruks, as giant collapse dolines caused by hypogenic karstification in central Anatolia, Turkey: analysis of likely formation processes. Hydrogeol J 17: 327-345. https://doi.org/10.1007/s10040-008-0351-9

Bayari CS, Özyurt NN, Törk AK, Avci P, Güner IN, Pekkan E (2017) Geodynamic control of hypogene karst development in central Anatolia, Turkey. In: Klimchouk A, Palmer A, De Waele J, Auler A, Audra P (eds) Hypogene karst regions and caves of the world. Cave and karst systems of the world book series, Springer, Cham, Switzerland, pp 449-462, https://doi.org/10.1007/978-3-31953348-3 27

Boev B, Jančev M (2014) Geochemistry and origine of thermo-mineral waters on Kožuf Mountain. Geol Macedonica 28(2):165-174

Boev B, Lepitkova S (2003) Geohemiski karakteristiki na termomineralnite void na planinata Kožuf [Geochemical characteristics of the thermomineral waters of Kožuf Mt]. Vtoro sovetuvanje za geotermalna energija vo Republika Makedonija [Second Geothermal Energy Conference in the Republic of Macedonia] 2003, pp 61-64

Burchfiel BC, Nakov R, Dumurdžanov N, Papanikolaou D, Tzankov T, Serafimovski T, King RW, Kotzev V, Todosov A, Nurce B (2008) Evolution and dynamics of the Cenozoic tectonics of the South Balkan extensional system. Geosphere 4:919-938. https://doi.org/ 10.1130/GES00169.1

Chiodini G, Frondini F, Cardellini C, Parello F, Peruzzi L (2000) Rate of diffuse carbon dioxide earth degassing estimated from carbon balance of regional aquifers: the case of central Apennine, Italy. J Geophys Res 105:8423-8434. https://doi.org/10.1029/ 1999JB900355

Chiodini G, Cardellini C, Amato A, Boshi E, Caliro S, Frondini F, Ventura $G$ (2004) Carbon dioxide earth degassing and 
seismogenesis in central and southern Italy. Geophys Res Lett 31(7): L07615. https://doi.org/10.1029/2004GL019480

Clark I (2015) Groundwater geochemistry and isotopes. Taylor and Francis, Abingdon, UK

Clark ID, Fritz P, Souther JG (1989) Geochemistry and isotope hydrogeology of the Mount Edziza-Mess Creek geothermal area. Can J Earth Sci 26:1160-1171. https://doi.org/10.1139/e89-099

Crossey L, Karlstrom K, Springer A, Newell D, Hilton D, Fischer T (2009) Degassing of mantle-derived $\mathrm{CO}_{2}$ and he from springs in the southern Colorado plateau region: neotectonic connections and implications for groundwater systems. GSA Bull 121(7-8):1034 1053. https://doi.org/10.1130/B26394.1

Daskalopoulou K, Calabrese S, Grassa F, Kyriakopoulos K, Parello F, Tassi F, D'Alessandro W (2018) Origin of methane and light hydrocarbons in natural fluid emissions: a key study from Greece. Chem Geol 479:286-301. https://doi.org/10.1016/j.chemgeo.2018. 01.027

De Waele J, Audra P, Madonia G, Vattano M, Plan L, D'Angeli IM, Bigot J-Y, Nobécourt J-C (2016) Sulfuric acid speleogenesis (SAS) close to the water table: examples from southern France, Austria, and Sicily. Geomorphology 253:452-467. https://doi.org/ 10.1016/j.geomorph.2015.10.019

Dublyansky YV (2000) Hydrothermal speleogenesis: its settings and peculiar features. In: Klimchouk AB, Ford DC, Palmer AN, Dreybrodt W (eds) Speleogenesis evolution of karst aquifers. National Speleological Society, Huntsville, AL, pp 298-303

Dubois C, Quinif Y, Baele J-M, Barriquand L, Bini A, Bruxelles L, Dandurand G, Havron C, Kaufmann O, Lans B, Maire R, Martin J, Rodet J, Rowberry MD, Tognini P, Vergari A (2014) The process of ghost-rock karstification and its role in the formation of cave systems. Earth Sci Rev 131:116-148. https://doi.org/10.1016/j. earscirev.2014.01.006

Dumurdžanov N, Serafimovski T, Burchfiel BC (2005) Cenozoic tectonics of Macedonia and its relation to the South Balkan extensional regime. Geol Soc Am: Geosphere 1(1):1-22. https://doi.org/10. 1130/GES00006.1

Erőss A, Mádl-Szőnyi J, Surbeck H, Horváth Á, Goldscheider N, Csoma AÉ (2012) Radionuclides as natural tracers for the characterization of fluids in regional discharge areas, Buda thermal karst, Hungary. J Hydrol 426-427:124-137. https://doi.org/10.1016/j.jhydrol.2012. 01.031

Erőss A, Csondor K, Czuppon G, Dezső J, Müller I (2020) Groundwater flow system understanding of the lukewarm springs in Kistapolca (South Hungary) and its relevance to hypogene cave formation. Environ Earth Sci 79:132. https://doi.org/10.1007/s12665-0208870-3

Fontes J-C, Garnier JM (1979) Determination of the initial activity of the total dissolved carbon: a review of existing models and a new approach. Water Resour Res 12:399-413. https://doi.org/10.1029/ WR015i002p00399

Ford D, Williams P (2007) Karst hydrogeology and geomorphology, 2nd edn. Wiley, Chichester, UK

Fournier R (1977) Chemical geothermometers and mixing models for geothermal systems. Geothermics 5:41-50. https://doi.org/10. 1016/0375-6505(77)90007-4

Fournier R, Potter R (1979) Magnesium correction to the Na-K-Ca chemical geothermometer. Geochim Cosmochim Acta 43:1543-1550. https://doi.org/10.1016/0016-7037(79)90147-9

Fournier R, Truesdell A (1973) An empirical Na-K-Ca geothermometer for natural water. Geochim Cosmochim Acta 37:1255-1275. https:// doi.org/10.1016/0016-7037(73)90060-4

Galdenzi S, Cocchioni M, Morichetti L, Amici V, Scuri S (2008) Sulfidic ground-water chemistry in the Frasassi caves, Italy. J Cave Karst Stud 70(2):94-107

Gary MO, Sharp JM (2006) Volcanogenic karstification of Sistema Zacatón, Mexico. In: Harmon RS, Wicks CW (eds) Perspectives on karst meomorphology, hydrology and geochemistry. GSA Special Paper 404, GSA, Boulder, CO, pp 79-89

Giggenbach W (1988) Geothermal solute equilibria. Derivation of Na-KMg-Ca geoindicators. Geochim Cosmochim Acta 52:2749-2765. https://doi.org/10.1016/0016-7037(88)90143-3

Goldscheider N, Mádl-Szőnyi J, Erőss A, Schill E (2010) Review: Thermal water resources in carbonate rock aquifers. Hydrogeol $\mathrm{J}$ 18(6):1303-1318. https://doi.org/10.1007/s10040-010-0611-3

Gonfiantini R, Zuppi GM (2003) Carbon exchange rate of DIC in karst groundwater. Chem Geol 197:319-336. https://doi.org/10.1016/ S0009-2541(02)00402-3

Gunn J, Bottrell SH, Lowe DJ, Worthington SRH (2006) Deep groundwater flow and geochemical processes in limestone aquifers: evidence from thermal waters in Derbyshire, England, UK. Hydrogeol J 14:868-881. https://doi.org/10.1007/s10040-006-0022-7

Han LF, Plummer LN (2016) A review of single-sample-based models and other approaches for radiocarbon dating of dissolved inorganic carbon in groundwater. Earth Sci Rev 152:119-142. https://doi.org/ 10.1016/j.earscirev.2015.11.004

Hertelendi E, Veres M, Futó I, Svingor É, Mikó L, Lénárt L, Deák J, Süveges M (1995) Radiocarbon concentration and origin of thermal karst waters in the region of the Bükk Mountains, northeastern Hungary. Radiocarbon 37(2):543-550. https://doi.org/10.1017/ S0033822200031039

Hua Q, Barbetti M, Rakowski AZ (2013) Atmospheric radiocarbon for the period 1950-2010. Radiocarbon 55(4):2059-2072. https://doi. org/10.2458/azu_js_rc.v55i2.16177

Ingerson E, Pearson FJ (1964) Estimation of age and rate of motion of groundwater by the 14C-method. In: Miyake Y, Koyama T (eds) Recent researches in the field of hydrosphere. Atmosphere and Nuclear Geochemistry, Tokyo, pp 263-228

Jasechko S, Birks SJ, Gleeson T, Wada Y, Fawcett PJ, Sharp ZD, McDonnell JJ, Welker JM (2014) The pronounced seasonality of global groundwater recharge. Water Resour Res 50:8845-8867. https://doi.org/10.1002/2014WR015809

Klimchouk AB (2007) Hypogene speleogenesis: hydrogeological and morphogenetic perspective. Special paper 1, National Cave and Karst Research Institute, Carlsbad, NM, 106 pp

Klimchouk A (2017) Types and settings of hypogene karst. In: Klimchouk A, Palmer A, De Waele J, Auler A, Audra P (eds) Hypogene karst regions and caves of the world. Cave and Karst Systems of the World book series, Springer, Cham, Switzerland, pp 1-39, https://doi.org/10.1007/978-3-319-53348-3_1

Klimchouk A, Palmer AN, De Waele J, Auler AS, Audra P (2017) Hypogene karst regions and caves of the world. Cave and Karst Systems of the World book series, Springer, Cham, Switzerland. https://doi.org/10.1007/978-3-319-53348-3

Kotevski G (1987) Hidrogeologija na mineralnite, termalnite i termomineralnite vodi na teritorijata na Socijalistička Republika Makedonija [Hydrogeology of the mineral, thermal and thermomineral waters on the territory of Socialist Republic of Macedonia]. Samupravna praktika, Skopje, Macedonia

Mádl-Szőnyi J, Tóth Á (2015) Basin-scale conceptual groundwater flow model for an unconfined and confined thick carbonate region. Hydrogeol J 23(7):1359-1380. https://doi.org/10.1007/s10040015-1274-x

McKenzie W, Truesdell A (1977) Geothermal reservoir temperatures estimated from the oxygen isotope compositions of dissolved sulfate and water from hot springs and shallow drillholes. Geothermics 5: 51-61. https://doi.org/10.1016/0375-6505(77)90008-6

Minissale A, Vaselli O, Tassi F, Magro G, Grechi GP (2002) Fluid mixing in carbonate aquifers near Rapolano (central Italy): chemical and isotopic constraints. Appl Geochem 17:1329-1342. https://doi. org/10.1016/S0883-2927(02)00023-9

Molnár M, Janovics R, Major I, Orsovszki J, Gönczi R, Veres M, Leonard AG, Castle SM, Lange TE, Wacker L, Hajdas I, Jull AJT 
(2013a) Status report of the new AMS ${ }^{14} \mathrm{C}$ sample preparation lab of the Hertelendi Laboratory of Environmental Studies (Debrecen, Hungary). Radiocarbon 55(2-3):665-676. https://doi.org/10.2458/ azu_js_rc.55.16394

Molnár M, Rinyu L, Veres M, Seiler M, Wacker L, Synal H-A (2013b) EnvironMICADAS: a mini ${ }^{14} \mathrm{C}$ AMS with enhanced gas ion source Interface in the Hertelendi Laboratory of Environmental Studies (HEKAL), Hungary. Radiocarbon 55(2):338-344. https://doi.org/ $10.2458 / \mathrm{azu}$ js rc.55.16331

Mook WG (1980) Carbon-14 in hydrogeological studies. In: Fritz P, Fontes JC (eds) Handbook of environmental isotope geochemistry. Elsevier, Amsterdam, pp 49-74

Most T (2003) Geodynamic evolution of the Eastern Pelagonian Zone in northwestern Greece and the Republic of Macedonia: implications from $\mathrm{U} / \mathrm{Pb}, \mathrm{Rb} / \mathrm{Sr}, \mathrm{K} / \mathrm{Ar}, 40 \mathrm{Ar} / 39 \mathrm{Ar}$ geochronology and fission track thermochronology. PhD Thesis, University of Tübingen, Tübingen, Germany, $98 \mathrm{pp}$

Ozima M, Podosek FA (2002) Noble gas geochemistry, 2nd edn. Cambridge University Press, Cambridge, UK

Paceš T (1975) A systematic deviation from Na-K-ca geothermometer below $75^{\circ} \mathrm{C}$ and above $10^{-4}$ atm $\mathrm{PCO}_{2}$. Geochim Cosmochim Acta 39:541-544. https://doi.org/10.1016/0016-7037(75)90108-8

Palcsu L, Major Z, Köllö Z, Papp L (2010) Using an ultrapure ${ }^{4} \mathrm{He}$ spike in tritium measurements of environmental water samples by the ${ }^{3}$ He-ingrowth method. Rapid Commun Mass Spectrom 24:698704. https://doi.org/10.1002/rcm.4431

Palinkaš S, Hofstra A, Percival T, Borojević Šoštarić S, Palinkaš L, Bermanec V, Pecskay Z, Boev B (2018) Comparison of the Allchar Au-As-Sb-Tl deposit, Republic of Macedonia, with Carlin-type gold deposits. In: Muntean J (ed) diversity in Carlinstyle gold deposits. Rev Econ Geol 20:335-363. https://doi.org/10. $5382 / \mathrm{rev} .20 .10$

Palmer AN (2007) Cave geology. Cave Books, Dayton, OH

Palmer AN, Taylor PM, Terrell LA (2017) Hypogene karst springs along the northeastern border of the Appalachian Plateau, New York State. In: Klimchouk A, Palmer A, De Waele J, Auler A, Audra P (eds) Hypogene karst regions and caves of the world. Cave and karst systems of the world book series, Springer, Cham, Switzerland, pp 709-719. https://doi.org/10.1007/978-3-319-53348-3 47

Papp L, Palcsu L, Major Z, Rinyu L, Tóth I (2012) A mass spectrometric line for tritium analysis of water and noble gas measurements from different water amounts in the range of microlitres and millilitres. Isot Environ Health Stud 48(1):494-451. https://doi.org/10.1080/ 10256016.2012.679935

Parkhurst DL, Appelo CAJ (2013) Description of input and examples for PHREEQC version 3: a computer program for speciation, batchreaction, one-dimensional transport, and inverse geochemical calculations. US Geological Survey Techniques and Methods, 6, A43, 497 pp. https://pubs.usgs.gov/tm/06/a43/. Accessed December 2020

Plan L, Tschegg C, De Waele J, Spötl C (2012) Corrosion morphology and cave wall alteration in an Alpine sulfuric acid cave (Kraushöhle, Austria). Geomorphology 169-170:45-54. https://doi.org/10.1016/ j.geomorph.2012.04.006

Plummer LN, Prestemon EC, Parkhurst DL (1994) An interactive code (NETPATH) for modeling net geochemical reactions along a flow path, version 2.0. US Geol Surv Water Resour Invest Rep 94-4169. https://doi.org/10.3133/wri944169

Rinyu L, Molnár M, Major I, Nagy T, Veres M, Kimák Á, Wacker L, Synal H-A (2013) Optimization of sealed tube graphitization method for environmental ${ }^{14} \mathrm{C}$ studies using MICADAS. Nucl Inst Methods Phys Res B 294:270-275. https://doi.org/10.1016/j.nimb. 2012.08.042

Santaloia F, Zuffianò LE, Palladino G, Limoni PP, Liotta D, Minissale A, Brogi A, Polemio M (2016) Coastal thermal springs in a foreland setting: the Santa Cesarea Terme system (Italy). Geothermics 64: 344-361. https://doi.org/10.1016/j.geothermics.2016.06.013

Schlosser P, Stute M, Dörr C, Sonntag C, Münnich KO (1988) Tritium $/{ }^{3} \mathrm{He}$-dating of shallow groundwater. Earth Planet Sci Lett 89:353-362. https://doi.org/10.1016/0012-821X(88)90122-7

Spötl C, Desch A, Dublyansky Y, Plan L, Mangini A (2016) Hypogene speleogenesis in dolomite host rock by $\mathrm{CO} 2$-rich fluids, Kozak cave (southern Austria). Geomorphology 255:39-48. https://doi.org/10. 1016/j.geomorph.2015.12.001

Sracek O, Geršl M, Faimon J, Bábek O (2019) The geochemistry and origin of fluids in the carbonate structure of the Hranice karst with the world's deepest flooded cave of the Hranicka abyss, Czech Republic. Appl Geochem 100:203-212. https://doi.org/10. 1016/j.apgeochem.2018.11.013

Tamers MA (1975) Validity of radiocarbon dates on groundwater. Geophys Surv 2:217-239. https://doi.org/10.1007/BF01447909

Temovski M (2016) Evolution of karst in the lower part of Crna Reka river basin. Springer Theses, Springer, Cham, Switzerland. https:// doi.org/10.1007/978-3-319-24547-8

Temovski M (2017) Hypogene karst in Macedonia. In: Klimchouk A, Palmer A, De Waele J, Auler A, Audra P (eds) Hypogene karst regions and caves of the world. Cave and karst systems of the world book series, Springer, Cham, Switzerland, pp 241-256. https://doi. org/10.1007/978-3-319-53348-3_15

Temovski M, Palcsu L (2018) Geochemical characteristics of some thermal karst springs: insight into the hypogene karst systems in Mariovo, Macedonia. In: Milanović S, Stevanović Z (eds) Proceedings of the International Symposium KARST 2018 Expect the Unexpected, Trebinje, Bosnia and Herzegovina, June 2018, pp 223-230

Temovski M, Audra P, Mihevc A, Spangenberg J, Polyak V, McIntosh W, Bigot J-Y (2013) Hypogenic origin of Provalata Cave, Republic of Macedonia: a distinct case of successive thermal carbonic and sulfuric acid speleogenesis. Int J Speleol 42(3):235-264. https:// doi.org/10.5038/1827-806X.42.3.7

Temovski M, Futó I, Túri M, Palcsu L (2018) Sulfur and oxygen isotopes in the gypsum deposits of the Provalata sulfuric acid cave (Macedonia). Geomorphology 315:80-90. https://doi.org/10.1016/ j.geomorph.2018.05.010

Vodila G, Palcsu L, Futó I, Zs S (2011) A 9-year record of stable isotope ratios of precipitation in eastern Hungary: implications on isotope hydrology and regional palaeoclimatology. J Hydrol 400:144-153. https://doi.org/10.1016/j.jhydrol.2011.01.030

Webb JA, Grimes KG, Lewis ID (2010) Volcanogenic origin of cenotes near Mt Gambier, southeastern Australia. Geomorphology 119(1): 23-35. https://doi.org/10.1016/j.geomorph.2010.02.015

Wynn JG, Sumrall JB, Onac BP (2010) Sulfur isotopic composition and the source of dissolved sulfur species in thermo-mineral springs of the Cerna Valley, Romania. Chem Geol 271:31-43. https://doi.org/ 10.1016/j.chemgeo.2009.12.009

Publisher's note Springer Nature remains neutral with regard to jurisdictional claims in published maps and institutional affiliations. 